Florida International University

FIU Digital Commons

FIU Electronic Theses and Dissertations

University Graduate School

$10-23-2014$

\title{
The Effect of Authentic Literacy Experiences as Book Buddies with Hispanic Fourth Graders on Preservice Teachers' Literacy Content Knowledge and Reading Maturity
}

Vivian L. Veiga

Florida International University, vveig001@fiu.edu

DOI: $10.25148 /$ etd.FI14110746

Follow this and additional works at: https://digitalcommons.fiu.edu/etd

Part of the Curriculum and Instruction Commons

\section{Recommended Citation}

Veiga, Vivian L., "The Effect of Authentic Literacy Experiences as Book Buddies with Hispanic Fourth Graders on Preservice Teachers' Literacy Content Knowledge and Reading Maturity" (2014). FIU Electronic Theses and Dissertations. 1634.

https://digitalcommons.fiu.edu/etd/1634

This work is brought to you for free and open access by the University Graduate School at FIU Digital Commons. It has been accepted for inclusion in FIU Electronic Theses and Dissertations by an authorized administrator of FIU Digital Commons. For more information, please contact dcc@fiu.edu. 


\title{
FLORIDA INTERNATIONAL UNIVERSITY \\ Miami, Florida
}

THE EFFECT OF AUTHENTIC LITERACY EXPERIENCES AS BOOK BUDDIES WITH HISPANIC FOURTH GRADERS ON PRESERVICE TEACHERS' LITERACY

CONTENT KNOWLEDGE AND READING MATURITY

\author{
A dissertation submitted in partial fulfillment of \\ the requirements for the degree of \\ DOCTOR OF EDUCATION \\ in \\ CURRICULUM and INSTRUCTION \\ by
}

Vivian Lucia Veiga

2014 
To: Dean Delia C. Garcia

College of Education

This dissertation, written by Vivian Lucia Veiga, and entitled The Effect of Authentic Literacy Experiences as Book Buddies with Hispanic Fourth Graders on Preservice Teachers' Literacy Content Knowledge and Reading Maturity, having been approved in respect to style and intellectual content, is referred to you for judgment.

We have read this dissertation and recommend that it be approved.

$\begin{array}{r}\hline \text { Leonard Bliss } \\ \hline \text { Hilary Landorf } \\ \hline \text { Lynne Miller } \\ \hline \text { Joyce C. Fine, Major Professor }\end{array}$

Date of Defense: October 23, 2014

The dissertation of Vivian Lucia Veiga is approved.

Dean Delia C. Garcia
College of Education

Dean Lakshmi N. Reddi

University Graduate School

Florida International University, 2014 
(C) Copyright 2014 by Vivian Lucia Veiga

All rights reserved. 


\section{DEDICATION}

First and foremost I would like to dedicate this dissertation to my son, Erik and to my daughter, Leslie. Their love, unconditional support and encouragement with my dissertation process, as well as with all of my many endeavors, qualify them not only for a special place in Heaven but also in my heart! I couldn't have done it without them. I am truly blessed to have such amazing young adults to call my own. Saying thank you doesn't begin to express my love and gratitude but it is a start!

I also dedicate this dissertation to my parents the late Carlos Luis and Ana Aspuru who from a very early age instilled in me a great love and respect for learning as well as a commitment to finish what I began. That commitment to finishing has definitely served me well throughout my life and it as well as the love of learning is reflected in my completion of this great endeavor.

In addition I would also like to dedicate this dissertation to my aunt and uncle the late Estela and Mauricio Almagro who always encouraged me and cheered me on in all of my pursuits.

Finally I would also like to recognize and dedicate this dissertation to my friends Vivian del Rio and Isela Rodriguez without whose unconditional support, assistance and friendship I would not have been able to achieve this great accomplishment. Thank you both from the bottom of my heart. 


\section{ACKNOWLEDGMENTS}

I would like to acknowledge and thank the many individuals who have provided assistance and support with my dissertation. First I would like to acknowledge my dissertation committee: Dr. Leonard Bliss, Dr. Hilary Landorf, Dr. Lynne Miller, and, my committee chairperson Dr. Joyce C. Fine. Thank you all for your feedback. In particular I would like to give a special thank you to Dr. Joyce C. Fine for all of your feedback, support and for reinforcing, without even knowing it, my parents' teachings that I must persevere to achieve my goals. I am also very grateful to Dr. Leonard Bliss for his guidance with the data analysis. Additionally I would like to acknowledge and thank all of my professors throughout my doctorate. Your teachings have served me well. I also want to thank Caprila Almeida for your hard work, dedication and for coming to the rescue every time.

A very special thank you goes to Dr. Kathleen P. Caballero, my former principal. You not only believed in me, you also encouraged me to reach new heights, and then, you provided the support to make it happen. Much of what I have accomplished began because of your belief in me. Thank you! I would also like to thank the administration at Kensington Park Elementary for their support and for allowing me to implement my study at KPE. A special thank you goes to Dr. Vivian del Rio, her students and mine, the preservice teachers and professors for participating in this study.

Additionally I would like to thank my entire family and friends for your words of encouragement and love. You always said you knew I could do it and I finally have! In closing I would like to thank God for giving me the strength, health and guidance to bring this dissertation to a successful conclusion. 


\title{
ABSTRACT OF THE DISSERTATION
}

\section{THE EFFECT OF AUTHENTIC LITERACY EXPERIENCES AS BOOK BUDDIES WITH HISPANIC FOURTH GRADERS ON PRESERVICE TEACHERS' LITERACY CONTENT KNOWLEDGE AND READING MATURITY}

\author{
by \\ Vivian Lucia Veiga \\ Florida International University, 2014 \\ Miami, Florida \\ Professor Joyce C. Fine, Major Professor
}

From a sociocultural perspective, individuals learn best from contextualized experiences. In preservice teacher education, contextualized experiences include authentic literacy experiences, which include a real reader and writer and replicate real life communication. To be prepared to teach well, preservice teachers need to gain literacy content knowledge and possess reading maturity. The purpose of this study was to examine the effect of authentic literacy experiences as Book Buddies with Hispanic fourth graders on preservice teachers' literacy content knowledge and reading maturity.

The study was a pretest/posttest design conducted over 12 weeks. Preservice teacher participants, the focus of the study, were elementary education majors taking the third of four required reading courses in non-probabilistic convenience groups, 43 ( $n=33$ experimental, $n=10$ comparison) Elementary Education majors. The Survey of Preservice Teachers' Knowledge of Teaching and Technology (SPTKTT), specifically designed for preservice teachers majoring in elementary or early childhood education and the Reading Maturity Survey (RMS) were used in this study. Preservice teachers chose 
either the experimental or comparison group based on the opportunity to earn extra credit points $($ experimental $=30$ points, comparison $=15)$. After exchanging introductory letters preservice teachers and Hispanic fourth graders each read four books. After reading each book preservice teachers wrote letters to their student asking higher order thinking questions. Preservice teachers received scanned copies of their student's unedited letters via email which enabled them to see their student's authentic answers and writing levels.

A series of analyses of covariance were used to determine whether there were significant differences in the dependent variables between the experimental and comparison groups. This quasi-experimental study tested two hypotheses. Using the appropriate pretest scores as covariates for adjusting the posttest means of the subcategory Literacy Content Knowledge (LCK), of the SPTKTT and the RMS, the mean adjusted posttest scores from the experimental group and comparison group were compared. No significant differences were found on the LCK dependent variable using the .05 level of significance, which may be due to Type II error caused by the small sample size. Significant differences were found on RMS using the .05 level of significance. 


\section{TABLE OF CONTENTS}

CHAPTER

PAGE

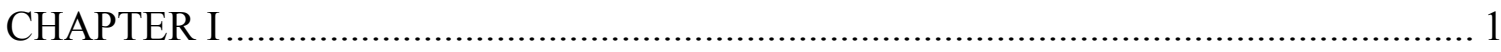

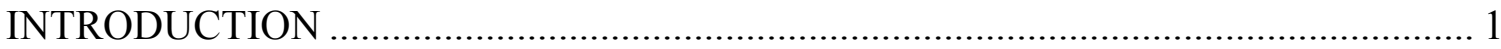

Background and Theory....................................................................................... 1

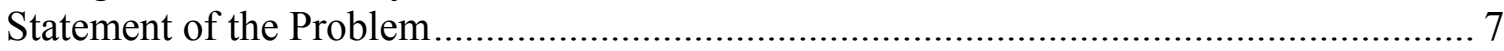

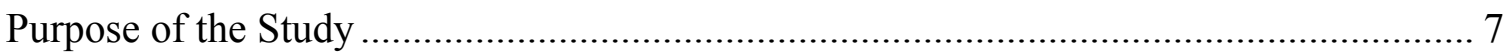

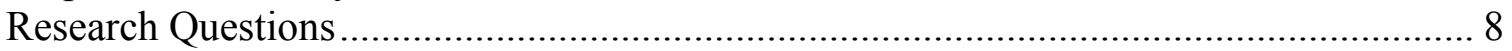

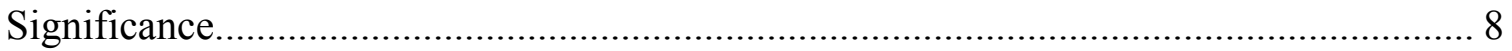

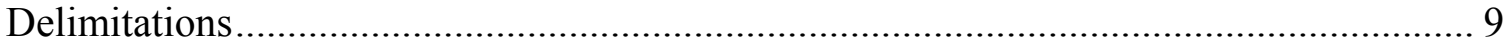

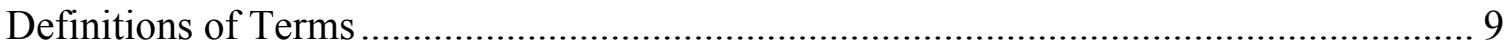

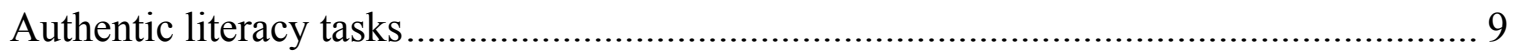

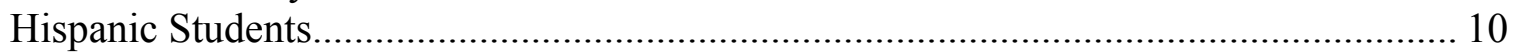

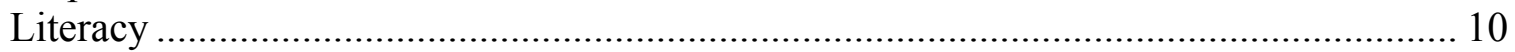

Literacy Content Knowledge ........................................................................... 10

Literacy Teacher Education ............................................................................... 10

Low Socio-Economic Status (SES), ..................................................................... 10

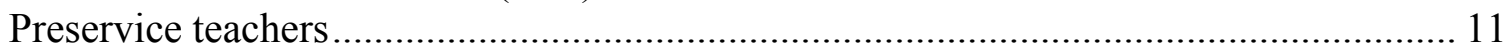

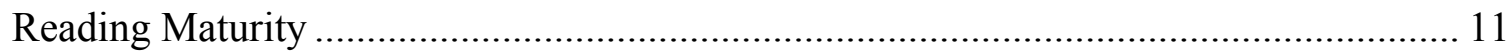

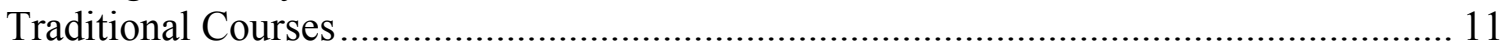

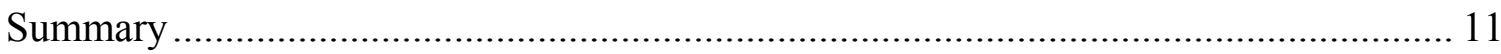

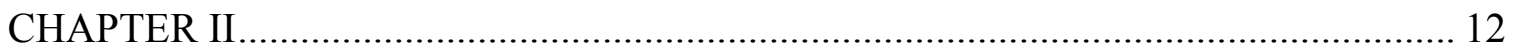

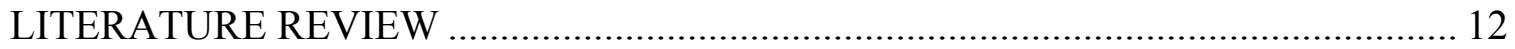

Defining Literacy, Literacy Teacher Education and Authentic Literacy Activities ......... 12

Improving Literacy Teacher Education ................................................................. 14

Expectations for Preservice Teacher Training ............................................................... 18

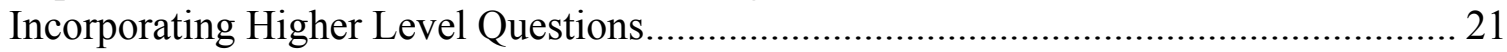

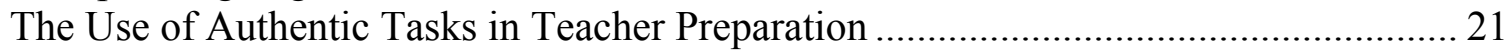

What Preservice Teachers Have Learned and Subsequently Implemented....................... 25

Measuring Changes in Preservice Teachers' Pedagogical And Content Knowledge....... 25

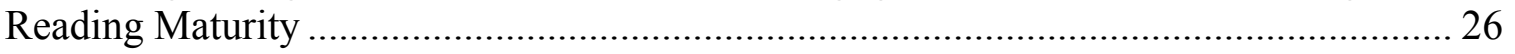

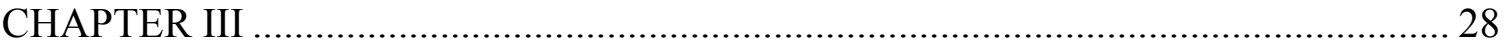

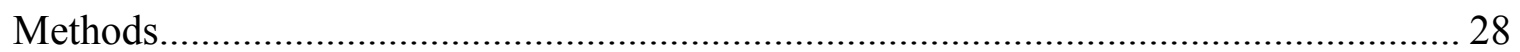

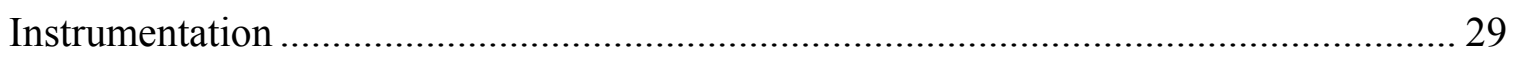

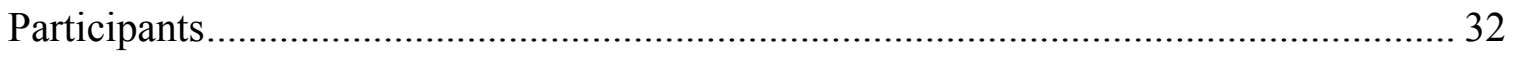

Research Questions and Hypotheses .......................................................................... 33

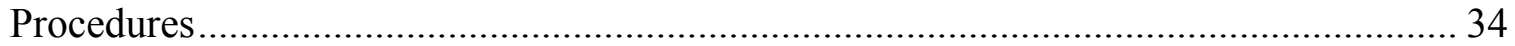

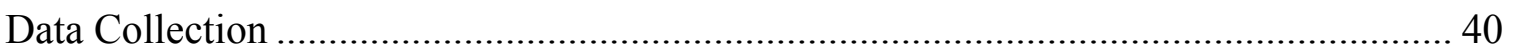

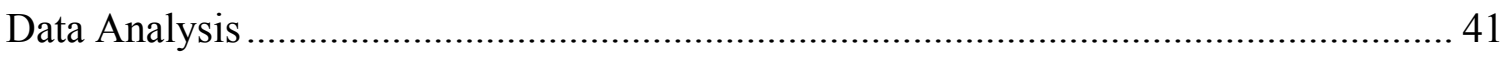

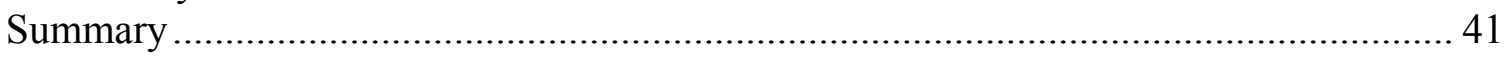




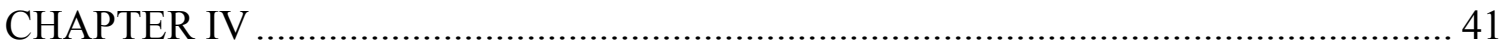

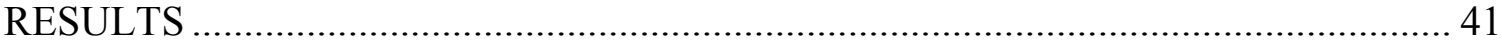

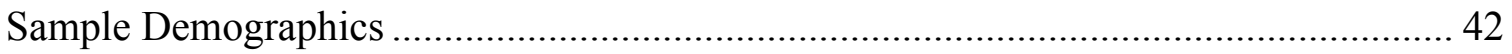

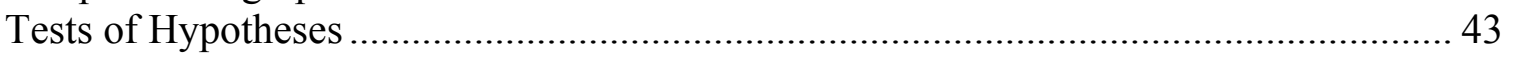

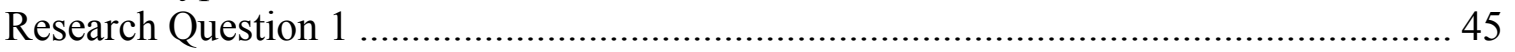

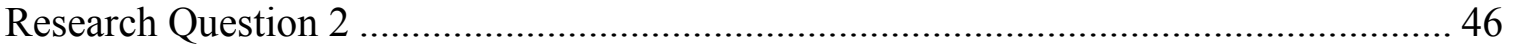

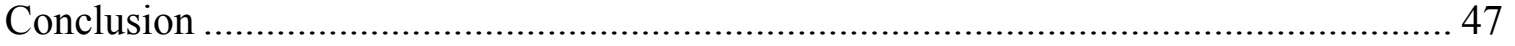

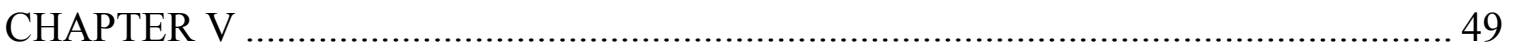

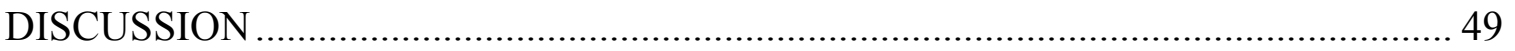

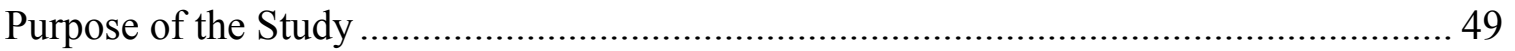

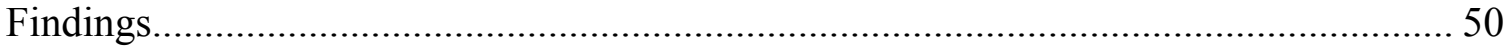

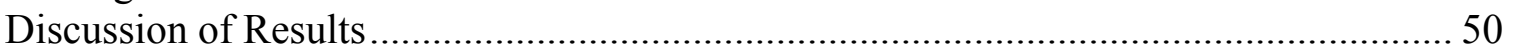

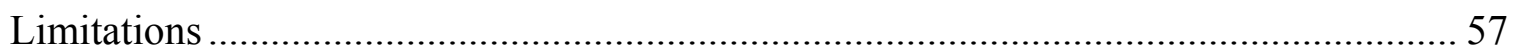

Recommendations for Future Research ................................................................ 58

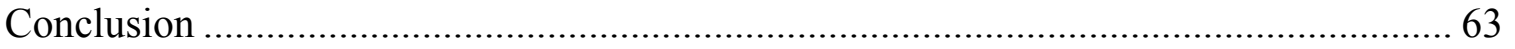

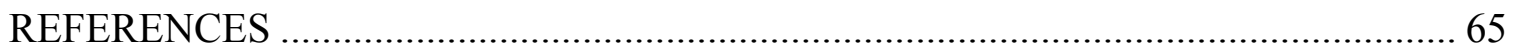

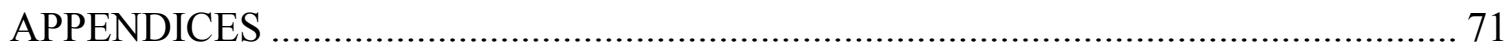

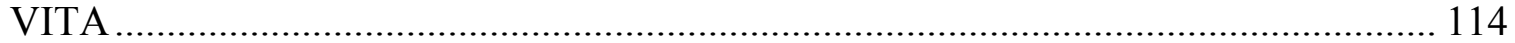




\section{CHAPTER I}

\section{INTRODUCTION}

From a sociocultural perspective (Vygotsky, 1978), knowledge construction is a social process and begins with children's interaction with parents and teachers. Cognitive processes are context specific. This means that individuals learn best when they are allowed to engage in authentic, contextualized activities. From an interactive perspective on reading and writing, meaning is constructed through social negotiation that depends on supportive interaction with others. Students learn the cognitive processes related to reading and writing best through contextualized activity and assisted learning (Englert \& Palincsar, 1991) and meaningful enterprise rather than learning in a mechanistic way (Raphael \& Englert, 1989). Given that learning within an authentic context is important for students, it may be as important for the learning of preservice teachers in their teacher preparation program.

The purpose of this chapter is to present the background and theory, statement of the problem, goals of this study, research questions, significance, delimitations, definition of terms and summary.

\section{Background and Theory}

Discussing the topic of the research base on authenticity and its positive effects on adult learners, Purcell-Gates, Degener, Jacobson, \& Soler, (2002) indicated that, in studying adult learners researchers found that when more authentic literacy activities were included in programs for them the adult learners reported reading and writing more often in real life as well as reading and writing more complex texts. Continuing on the 
topic of authenticity, Duke et al. (2006) provided an operational definition of authentic literacy activities as:

Those that replicate or reflect reading and writing activities that occur in the lives of people outside of a learning-to-read-and-write context and purpose. Each authentic literacy activity has a writer and a reader - a writer who is writing to a real reader and a reader who is reading what the writer wrote. (p.346)

On the topic of judging authenticity Duke et al. (2006) continued stating:

to judge the authenticity of a literacy activity, we look at two dimensions: purpose or function and text. Authentic purpose or function means that the activity serves a true communicative purpose" ... To be authentic, a text (written or read) must be like texts that are used by readers and writers outside of a learning-to-read-or-write context. (p. 346)

Referring to the work of Edelsky (1991) and Purcell-Gates (2002) while looking at authentic reading, writing, and discussion as part of studying the results of an exploratory pen pal project, Gambrell, Hughes, Calvert, Malloy and Igo (2011) indicated that "Authentic literacy tasks can be described as having three dimensions: meaning making, purpose, and ownership" (p. 236). Preservice teachers writing to fourth-grade students about a book that they had both read, as was done in the current study, is an example of an authentic literacy task since meaning making occurred: there was a purpose for writing and ownership of the letters as a result of being the authors of the letters. 
In an effort to motivate students to write and to change their attitudes towards writing, Tebo-Messina and Blough (1989) devised a project to give students pen pals, or key pals (since technology was used), as a real audience and found positive effects.

Teale, Zolt, Yokota, Glasswell, and Gambrell (2007) studied the effects of getting students "In2Books," as their program was called, by providing them with adult pen pals in an effort to develop high-level literacy. Other studies have examined the effects of preservice teachers as pen pals to elementary students and found that the relationships made a difference to the children as children learned about letter writing and reading in an authentic context writing real letters to real people, (Berril \& Gall, 1999). Children also gained confidence as they learned to take turns speaking during literature circles conducted with their preservice teacher (Day, 2009) but neither study examined the effects on preservice teachers as this study has done. The current study focused on the adult learners, the preservice teachers.

One aspect that may affect preservice teachers' ability to teach reading that of reading maturity, was explored by Theiss, Philbrick, and Jarman (2008-2009). Discussing the use of the Reading Maturity Survey, Theiss et al. (2008-2009) questioned whether there is a relationship between preservice teachers' reading maturity, which based on the work of Thomas (2001) is a self-report on one's reading attitudes and habits, and their disposition to teach reading. The researcher wondered how participation in authentic literacy experiences with diverse fourth grade students might affect preservice teacher's reading maturity levels. 
In looking at the topic of mentored learning to teach, Wang and Odell (2002), indicated:

Although the direct relationship between teachers' beliefs and their teaching practice is not consistently identified (Wideen, Mayer-Smith, and Moon, 1998), research on both preservice teachers and inservice teachers suggests that their personal dispositions toward teaching have a strong impact on what they are able to learn from their professional development opportunities (Richardson, 1996). (p. 485)

When preservice teachers have professional development opportunities for authentic literacy, based on Vygotsky's (1978) concept of the zone of proximal development, in which students are able to internalize from scaffolded experiences, and the research of Wang and Odell (2002), and extending the concept to reading maturity, it was reasonable to use the Reading Maturity Survey as an indicator of what preservice teachers are able to learn from their professional development opportunities.

Facilitating literacy discussions is something that few preservice teachers have the opportunity to practice (Groenke, 2008). Having implemented a carefully designed and prolonged treatment of technology integration in working with future teachers, Pierson (2004) concluded that true integration of technology during their teacher preparation experience will prepare future teachers to meet the challenges that come with the current demands of teaching which include using technology to facilitate communication. The teacher's ability to connect with students is enhanced through the use of technology. Carroll and Bowman (2000) and Medicus and Wood (2000) discussed technology's 
potential to engage students more actively with texts and the writing process. In analyzing preservice English teachers' perceptions and classroom practices, Pasternak (2007) found that preservice teachers needed opportunities to experiment with and incorporate technology usage beginning as early as their methods classes for technology to progress and to be considered as a regular part of the curriculum. According to Albion and Ertmer (2002) teachers' beliefs about teaching are likely formed by personal experiences both as a student and later when teaching. In addition the expectations of their peers as well as learners they are working with can also have an effect on teaching beliefs. For teachers to implement widespread use of technology in the classroom, they must believe that it will contribute to student learning (Lambert \& Gong, 2010) as well as have experienced it themselves. Based on the above research when literacy discussions and technology practice are incorporated into the learning experiences of preservice teachers they are more likely to subsequently incorporate them into their future teaching.

Wolf, Carey, and Mieras (1996) stated that preservice teachers must be involved with real children in addition to learning about them through books and articles. Learning from their coursework as well as by observing their professors in action, preservice teachers are learners who, in turn, become teachers applying what they have learned and observed in their classroom teaching (Solvie \& Kloek, 2007). In working with preservice teachers doing their internship, Holt, McAllister and Ingram (2001) found that through project learning activities preservice teachers developed their abilities to use technology and were effective in significantly enhancing classroom instruction and student learning. Bull et al (2008) suggest that preservice teachers use their knowledge of social media and various technologies in collaboration with teacher education faculty who possess the 
expertise in content and pedagogy to mutually find ways to incorporate and adapt social media and communication technologies for classroom use. The ability to teach comes not only from taking classes but also from firsthand experience. Dewey in Dewey, Boydston and Gouinlock (1984), when referring to teachers, wrote, "He has to see on his own behalf and in his own way the relations between means and methods employed and results achieved. Nobody else can see for him,” (1984, (p. 57). As Woodcock (2009) stated, "In order to teach students how to do something, teachers need to be doing it themselves." (p.95). Using technology to help facilitate literacy related communications with students, can provide preservice teachers with additional opportunities to gain information about students' literacy levels which can in turn further develop preservice teacher literacy knowledge.

Wold, Grisham, Farnan, and Lenski, (2008) examined the research on critical issues in literacy teacher education during the past 20 years and identified a total of 10 topics that were separated into three overall categories: candidate qualifications, program quality and rigor, and results and verification. The category of candidate qualifications included the topic of practicing skills and refining them in a systematic method as a way of developing literacy expertise. They included fieldwork, along with literacy teacher education courses, under the category of program quality and rigor. These ideas were incorporated three years later into Florida's Educator Accomplished Practices (FEAPs; 2011). The FEAPS set the foundational standards for the state's teacher preparation programs with literacy related concepts emphasized. Having the opportunity to engage in authentic literacy experiences with students helps give preservice teachers the opportunity to practice and develop their literacy skills. 


\section{Statement of the Problem}

It is important to conduct this study because there is a need for students to develop a high level of literacy skills for today's technological society. It is important that preservice teacher preparation include opportunities to gain technological content knowledge, so that the preservice teachers may teach literacy at high levels to their future students. While there has been research on student gains while engaging in the exchange of letters with adults there has been no research on the effects on preservice teachers of preservice teachers engaging in authentic literacy experiences with students. When there are diverse populations of students the issue of best practices in literacy teacher preparation is an area for study.

The research on contextualized activity and assisted learning with students (Englert \& Palincsar, 1991), meaningful enterprise (Raphael \& Englert, 1989), and the results of the authentic literacy activities with adult learners (Duke et al., 2006), necessitates that preservice teachers engage in authentic literacy experiences. In addition critical issues in literacy teacher education (Wold et al, 2008), and the need for candidates to develop literacy expertise (Florida Educator Accomplished Practices, 2011), also necessitates that preservice teachers engage in authentic literacy experiences.

\section{Purpose of the Study}

Providing preservice teachers, adults themselves, with the opportunity to engage in an authentic literacy experience model such as Book Buddies with Hispanic fourth grade students would suggest that preservice teachers, as adult learners may benefit from an authentic context for practicing their literacy teaching skills. 
The purpose of this study was to examine the effect of authentic literacy experiences as Book Buddies with Hispanic fourth graders on preservice teachers' literacy content knowledge and reading maturity. To address the need to offer preservice teachers opportunity to develop their literacy content knowledge and pedagogical knowledge and at the same time enhance their reading maturity, an authentic activity was arranged to exchange via email technology letters about books both they and fourth grade Hispanic students had read. By communicating with real students, the preservice teachers experienced the authentic writing and ideas that students were able to produce.

\section{Research Questions}

Question 1: Do preservice teachers who have engaged with authentic literacy experiences with Hispanic fourth graders as Book Buddies exhibit higher mean scores on the subcategory Literacy Content Knowledge (LCK) of The Survey of Preservice Teachers' Knowledge of Teaching and Technology than preservice teachers who do not experience being Book Buddies?

Question 2: Do preservice teachers who have engaged with authentic literacy experiences with Hispanic fourth graders as Book Buddies exhibit higher mean scores on the Reading Maturity Survey (RMS) than preservice teachers who do not experience being Book Buddies?

\section{Significance}

This study extends the research completed by Teale et al (2007) in the In2Books pen pal program which focused on children, to focus on preservice teachers as adult learners and Book Buddies. This study may be significant to faculty and administrators 
in Colleges of Education in terms of the development and use of authentic literacy experiences for preservice teachers.

\section{Delimitations}

The two delimitations for this study were as follows: The first was that the study was conducted during one semester in which preservice teachers were taking the third of four required reading courses. The delimitation of the preservice teachers being the ones taking the third of four required reading courses was set because there needed to be a common ground amongst the participants. By all being enrolled in the third of four required courses then they had all previously satisfied the requirements of the first two reading courses. By having satisfied the requirements of the first two reading courses they were expected to have the same knowledge base at the beginning of this study. The second delimitation was that there were two specific classes of Hispanic fourth graders. The delimitation of the two specific classes of Hispanic fourth graders was generated by the number of preservice teachers enrolled in the experimental group. If there had been additional preservice teachers that chose to participate in the study then the researcher would have made arrangements for additional fourth graders to participate as fourth grade book buddies.

\section{Definitions of Terms}

Authentic literacy tasks. As defined by this researcher authentic literacy tasks are when the preservice teachers and the fourth graders establish a dialogue when a preservice teacher writes a letter to a real reader, a student, and the student responds to that letter. 
What made them authentic literacy tasks was the exchange of letters between the preservice teachers and fourth grade students.

Hispanic Students. Hispanic, fourth-grade students whose native language is Spanish as verified by the Miami-Dade County Public Schools "Home Language Survey”, Form FM-5196ESH Rev. (09-09) completed by parents at registration and maintained in school records.

Literacy. For this study the researcher has selected the implicit definition of literacy presented by Cunningham (2000) that consists of three parts "(a) the ability to engage in some of the unique aspects of reading and writing, (b) contextualization to some extent within the broad demands of the society, and (c) some minimal level of practical proficiency" (p. 64).

Literacy Content Knowledge. As defined by this researcher literacy content knowledge is having knowledge about literacy, using a literary way of thinking and knowing different ways and strategies of developing ones' understanding of literacy.

Literacy Teacher Education. As defined by this researcher, based on Cunningham's (2000) implicit definition of literacy, literacy teacher education is education provided to preservice teachers that will enable them (a) to engage in and subsequently be prepared to teach aspects of reading and writing, (b) to contextualize and subsequently be prepared to teach the concept of contextualization based on society's demands and (c) to reach at least a minimal level of practical proficiency in teaching literacy.

Low Socio-Economic Status (SES). Low SES was defined in this dissertation as qualifying for free or reduced lunch and attending a school that is a part of a Title I schoolwide Program. According to the U. S. Department of Education a school is 
eligible to participate in a Title I Schoolwide Program when the poverty level (determined by free and reduced meals counts) Aid for Dependent Children [AFDC], census, or Medicaid is at or above $40 \%$. The school attended by the fourth graders in the study was at a $91 \%$ free and reduced meals status.

Preservice teachers. Preservice adults enrolled in the third of four reading courses working towards achieving teacher certification.

Reading Maturity. Reading Maturity is defined by the six categories of The Reading Maturity Survey. The six subcategories are: reading attitudes and interests; reading purposes; reading ability; reaction to and use of ideas to apprehend higher-order literacy; kind of materials read; and personal adjustment to reading/transformational reading. (Thomas, 2001).

Traditional Courses. As defined by this researcher, traditional courses are the courses that all preservice teachers studying to become elementary education teachers are required to take as a part of their course of study. The traditional courses at the university where the study was conducted include RED 3313 Language and Literacy Development, RED 4150 Content and Methods of Teaching Beginning Literacy, RED 4311 Content and Methods of Teaching Intermediate Literacy and RED 4110 Content and Methods of Teaching Literacy in Schools.

\section{Summary}

In summary, this chapter explained the background and theory, statement of the problem, goals of this study, research questions, significance, delimitations, definition of terms and summary. The next chapter reviews the literature related to the topic. 


\section{CHAPTER II}

\section{LITERATURE REVIEW}

This chapter will review the literature related to defining literacy, literacy teacher education and authentic literacy activities, improving literacy teacher education, expectations for preservice teacher training, incorporating higher level questions, the use of authentic tasks in teacher preparation, what preservice teachers have learned and subsequently implemented, measuring changes in preservice teachers' pedagogical and content knowledge, and reading maturity.

\section{Defining Literacy, Literacy Teacher Education and Authentic Literacy Activities}

Working on parameters that must be included in definitions of literacy, Bormuth (1973-1974) indicated that a true definition of literacy had not been established at that point in time, stating "Rather each definition must be designed for the purpose to which it is to be put, and its correctness may be judged only in terms of how well it serves that purpose" (p. 19). In limiting a definition, Bormuth goes on to state that "In the broadest sense of the word, literacy, is the ability to exhibit all of the behaviors a person needs in order to respond appropriately to all possible reading tasks" (p. 22). Based on a literature search, subsequent references to literacy only included references to responding to reading until the beginning of the twenty-first century.

Based on a current literature search, it was not until the year 2000 that the aspect of writing was included in references to literacy. In writing about possible definitions of literacy in the new millennium the implicit definition of literacy presented by Cunningham (2000) consists of three parts "(a) the ability to engage in some of the unique aspects of reading and writing, (b) contextualization to some extent within the 
broad demands of the society, and (c) some minimal level of practical proficiency" (p. 64). Cunningham's (2000) implicit definition of literacy is the one that this researcher has adapted to arrive at a definition of literacy in teacher education, because the researcher could not specifically locate an existing definition of literacy teacher education.

Literacy Teacher Education as defined by this researcher, based on Cunningham's (2000) implicit definition of literacy, is education provided to preservice teachers that will enable them (a) to engage in and subsequently be prepared to teach aspects of reading and writing, (b) to be able to contextualize and subsequently be prepared to teach the concept of contextualization and (c) to reach at least a minimal level of practical proficiency in teaching literacy.

Regarding authentic literacy activities Duke, Purcell-Gates, Hall \& Tower (2006) provide an operational definition stating

Conceptualize authentic literacy activities in the classroom as those that replicate or reflect reading and writing activities that occur in the lives of people outside of a learning-to-read-and-write context and purpose. Each authentic literacy activity has a writer and a reader - a writer who is writing to a real reader and a reader who is reading what the writer wrote (p. 346).

The current study provided the preservice teachers and the Hispanic fourth graders with authentic literacy activities as they read books and exchanged letters regarding the books that they have both read. 


\section{Improving Literacy Teacher Education}

This section addresses the literature on improving literacy teacher education. The studies by Tebo-Messina and Blough (1989) and Teale, Zolt, Yokata, Glasswell and Gambrell (2007) were directed at improving K-12 students' writing but lead to this study. In an effort to motivate students to write and to change their attitudes towards writing, Tebo-Messina and Blough (1989) devised a project to give students pen pals, or key pals (since technology was used), as a real audience, and found positive effects. Teale, Zolt, Yokota, Glasswell and Gambrell (2007) studied the effects of getting students "In2" books by providing them with adult pen pals in an effort to develop high-level literacy. They found that students scored significantly higher on standardized reading tests as a result. The classroom teacher in the current study, the researcher, participated in this program and wondered about the effects on preservice teachers if they were paired with her fourth grade students. Other studies have examined the effects of preservice teachers as pen pals to elementary students and found that the relationships made a difference to the children as children learned about letter writing and reading in an authentic context writing real letters to real people, (Berril \& Gall, 1999). Children also gained confidence as they learned to take turns speaking during literature circles conducted with their preservice teacher (Day, 2009) but neither study examined the effects on preservice teachers as this study has done.

Changes in learning environments, demographics, and technology have created a need to explore different methods for improving literacy teacher education. In an effort to go beyond the industrial-era model of schooling, in which there is a teacher and 
students within the confines of a school building, there is a need to connect students to adult role models in the community (Dede, 2010). According to the U.S. Department of Education's 2010 draft of the National Educational Technology Plan, a $21^{\text {st }}$ century model of formal education will prepare students for different learning environments of the future.

From a social perspective (Vygotsky, 1978), knowledge construction is a social process and begins with interaction with parents and teachers. Cognitive processes are context specific. This means that students learn best when they are allowed to engage in authentic, contextualized activities (Mayer, 1996). From a sociocultural perspective on reading and writing, we know that meaning is constructed through social negotiation that depends on supportive interaction with others. Students learn the cognitive processes related to reading and writing best through contextualized activity and assisted learning (Englert and Palincsar, 1991) and meaningful enterprise rather than learning in a mechanistic way (Raphael and Englert, 1989).

In discussing the opportunity of redefining literacy instruction Schmoker (2007) referred to authentic literacy as the "ability to read, write and think effectively" (p. 488) and indicated that an emphasis on authentic literacy skills should be at the top of the education reform agenda. According to Schmoker emphasizing authentic literacy skills could bring about many positive results including a narrowing of the achievement gap, intellectual development and higher test scores. Schmoker went on to state that "Changing to the pursuit of authentic literacy may be the simplest, most productive, and most enjoyable change we could make in our efforts to reduce the achievement gap and 
prepare students for life and learning" (p. 492). Duke, et al (2006) and Schmoker (2007) concur on the need for authenticity in literacy activities.

Studying the reading habits and attitudes of elementary preservice teachers Applegate and Applegate (2004) found that the elementary preservice teachers in the research study were "unenthusiastic readers" according to the results of two separate studies. According to the results in the first study $54.3 \%$ of the preservice teachers were "unenthusiastic readers" and in the follow-up study $48.4 \%$ overall were in the same category. Due to these results Applegate and Applegate (2004) began to refer to what they call the "Peter Effect as the condition characterizing those teachers who are charged with conveying to their students an enthusiasm for reading that they do not have." (p. 556). Applegate and Applegate indicate that institutions preparing teachers have "a serious obligation to address the nature of their students' attitudes toward reading." (p. 561) because the attitudes that teachers project towards reading affects the reading habits and attitudes of their students. They went on to discuss how the preservice teachers will ultimately display those unenthusiastic attitudes towards their future students if something is not done to help reverse that trend.

As one of several ways of addressing the situation of the unenthusiastic preservice teacher readers that they found in their studies Applegate and Applegate (2004) indicate that institutions preparing preservice teachers have an obligation to provide them with "experiences and models that will promote their own engagement in reading." (p. 562).

Nathanson, Pruslow and Levitt (2008) used the Literacy Habits Questionnaire developed by Applegate and Applegate (2004) to survey students who were enrolled in 
their university's graduate school of education. The results of their research indicated that only $47 \%$ of the students that participated considered themselves as enthusiastic or highly enthusiastic readers which led the researchers to also have concerns about "The Peter Effect" discussed by Applegate and Applegate (2004).

Nathanson, Pruslow and Levitt (2008) suggest including discussions of aliteracy, being able to read but not being interested in doing so, as a part of college courses as a way of bringing the problem into the open and beginning to deal with it.

In an expanded follow-up study across multiple universities on the reading habits and attitudes of 1,025 college students which included a subsection of 348 education majors or preservice teachers Applegate, Applegate, Mercantini, McGeehan, Cobb, DeBoy, Modla and Lewinski (2014) found that overall, education majors that included elementary to secondary in this study, were more enthusiastic readers than their classmates not studying to be teachers. The reading enthusiasm level of the preservice teachers was $51.1 \%$ compared to the $44.3 \%$ for the non-education majors. While Applegate, et al (2014) indicated that they found some reasons for encouragement due to the overall rise in preservice teachers' reading enthusiasm, as compared to their previous studies, they also state that the huge numbers of unenthusiastic readers are a continuing cause for concern that should be addressed by the education community. According to Applegate, et al (2014) finding ways to develop enthusiastic readers may be the way to break out of the "influence of the Peter Effect" (p. 200) which as previously referenced is the situation where one cannot give what one does not have. In the case of preservice 
teachers it refers to being unable to help students develop an enthusiasm for reading that they, the preservice teachers, do not themselves have.

The current study included the opportunity for preservice teachers to correspond with diverse fourth graders as they communicated about the books that both groups were reading. Participation in this study provided preservice teachers with the opportunity to learn through participation in a set of contextualized activities with fourth grade students in experiences that promoted engagement in reading.

\section{Expectations for Preservice Teacher Training}

The current study provided preservice teachers with the opportunity to communicate with fourth grade students by means of e-mail correspondence that was conducted throughout the study, providing opportunities for written literacy discussions.

Facilitating literacy discussions is something that few preservice teachers have the opportunity to practice (Groenke, 2008). Corresponding with the diverse, fourth-grade students and using comprehension and writing strategies to enhance real student learning, helps preservice teachers learn to teach with meaning and authenticity. Preservice teachers' ability to connect with students was enhanced through the use of e-mail.

Hinchman and Lalik (2000) examined their own practices as literacy teacher educators who wanted their students to develop a sense of confidence so they could handle varied situations as they arose in literacy education. By examining their teaching approaches in a variety of ways, they identified "power-knowledge formations" which considered the levels of equity and fairness in their discourse in their representations of literacy as they taught literacy skills to their students. According to Albion and Ertmer 
(2002) teacher's beliefs are formed by experiences and later reinforced by interactions with other professionals as well as by the expectations of the students in their classrooms. Wolf, Carey, and Mieras (1996) believe that preservice teachers must be involved with real children - moving beyond only reading about them in books and articles.

Learning from their coursework as well as by observing their professors in action, preservice teachers are learners who, in turn become teachers applying what they have learned and observed in their classroom teaching (Solvie \& Kloek 2007), while Shoffner (2009) noted the importance of technological content knowledge.

According to Dewey in Dewey, Boydston and Gouinlock, (1984) knowing how to teach comes not only from taking classes but also from firsthand experience: "He has to see on his own behalf and in his own way the relations between means and methods employed and results achieved. Nobody else can see for him," (p. 57). As Woodcock (2009) states, "In order to teach students how to do something, teachers need to be doing it themselves" (p. 95). As one of several ways of addressing the situation of the unenthusiastic preservice teacher readers that they found in their studies Applegate and Applegate (2004) indicate that institutions preparing preservice teachers have an obligation to provide them with "experiences and models that will promote their own engagement in reading." (p. 562).

Wold et al.'s (2008) examination of critical issues in literacy teacher education during the previous twenty years identified a total of ten topics which were separated into three overall categories: candidate qualifications, program quality and rigor, and results and verification. The category of candidate qualifications included the topic of practicing skills and refining them in a systematic method as a way of developing literacy expertise. 
Fieldwork, along with literacy teacher education courses, were included under program quality and rigor. (p. 12)

Three years later Florida's Educator Accomplished Practices (2011) set the core standards forming the foundation for the state's teacher preparation programs. It included "Instructional Delivery and Facilitation." It specifies that "The effective educator consistently utilizes a deep and comprehensive knowledge of the subject taught to..."Employ higher-order questioning techniques" (U.S. Department of Education, (6A5.065 The Educator Accomplished Practices. 2010).

In studying the topic of preservice teachers as writers Morgan (2010) discussed the issue that to teach writing well preservice teachers need to draw on their experiences to support their teaching. Morgan also recommended the idea of preservice teachers having writing experiences similar to that of their future students. According to the results of Morgan's study the preservice teacher participants found that writing like their students would be expected to write was very beneficial for them in helping them understand what children struggle with as they write.

In researching the topic of writing teacher education Morgan and Pytash (2014) conducted a review of 20 years' worth of the research literature on preparing preservice teachers to become teachers of writing. During their research Morgan and Pytash found twelve studies dealing with preservice teachers interacting with students and their writing. According to Morgan and Pytash in reviewing the findings across all twelve studies, they found that researchers had indicated that providing preservice teachers with opportunities to interact with students or with students' written work was an essential component in teaching preservice teachers to become teachers of writing. 
The current study not only allowed preservice teachers to write like their future students' could be expected to write; it also provided them with multiple opportunities to read and review authentic student writing written in response to their, the preservice teachers', authentic writing.

\section{Incorporating Higher Level Questions}

The Florida Educator Accomplished Practices (FEAP) are currently existing requirements for incorporating higher-order questioning techniques to meet educational goals. In the current study, preservice teachers used Tarlinton's (2003) Revised Bloom's Taxonomy, which included the work of Pohl (2000), as support when creating higher order open-ended comprehension questions in the levels of analyzing, evaluating and creating when composing their book related letters to their fourth grade Book Buddies. The book related letters provided an authentic literacy activity for the preservice teachers to practice incorporating higher-order questioning techniques in their practice.

\section{The Use of Authentic Tasks in Teacher Preparation}

This section addresses the use of authentic tasks in teacher preparation. The use of authentic tasks facilitated communication, problem solving, and critical thinking in written language acquisition (Charron, 2007) and was a part of effective classroom skill and strategy instruction (Mohan, Lundeberg and Reffitt, 2008). One authentic task was the use of student-only email which provided academic benefits and cultural exchange opportunities for students from all over the world (Demski, 2008). Studying factors that influenced children in a literacy experience with preservice teachers, Day's (2009) results 
suggest that children formed significant relationships, gained personal advocates as well as gaining confidence while participating in and managing literature circles. Monthly face-to-face literature circle meetings were held, either at the university or at the elementary school, during the preservice teachers scheduled class time. Thus, authentic tasks with personal relationships have been shown to support student literacy growth.

In exploring the use of authentic literature with adult learners Nixon-Ponder and Marshall (1996) shared that adult literacy teachers in Ohio were excited and amazed with the changes in their students behaviors. The behaviors they were referring to included attending class on a more regular basis, going to the library on their own time, actively discussing book plots and characters as well as relating those plots and characters to their own personal lives. Nixon-Ponder and Marshall went on to share that what was causing the differences in the students was that the adult literacy teachers had started implementing the practice of having their adult students reading authentic literature. Reading authentic literature was meaningful for the adult learners because according to Ponder-Nixon and Marshall "it connects adult learners with others' feelings and experiences while broadening their view of the world."

In sharing about using the writing of letters to support literacy LeVine (2002) indicated that meaningful communication is ultimately the purpose of reading and writing and that the writing of letters is an authentic form of written communication. Discussing ways of making writing authentic Daniels (2007) wrote about the implementation of a literacy café with students. Daniels stated that "Writing is authentic when the writer feels compelled to share it or when he or she has a personally relevant purpose". (p. 17) 
Daniels found that students were motivated to write when taught that writing is not something just for school that it is also used in the real world.

In discussing the case for authentic tasks in content literacy, Parsons and Ward (2011) indicated that the design and implementation of authentic tasks is a way of providing students with experiences which help them see the relevance in their academic work. They also indicate that authentic tasks can be help build students' vocabulary.

Discussing the concept of multiple literacies, using and learning from more than one source, Jewett (2011) pointed out that literacy learning does not happen in isolation from the rest of our lives, it is a part of it. Jewett continued indicating that it is necessary to embed authentic literacy practices in schools. Embedding authentic literacy practices in schools according to Jewett would support students and help make connections between what students learn and use in their daily out of school lives and what they are learning in school. Embedding authentic literacy practices in teacher preparation would support preservice teachers and help them make connections between what they are learning in their methods courses and what they will be using once they are actually teaching.

Discussing the importance of mapping today's literacy landscapes and suggesting steps for immediate implementation, Campbell and Parr (2013) indicated that learning should be taken beyond classroom walls and that teachers should plan for and help establish connections between in-school and out-of-school literacies and ways of learning. Taking learning out of the classroom for preservice teachers and helping them 
establish connections between in-school and out-of-school literacies and ways of learning would help make preservice teachers better prepared to teach.

In discussing the concept of literacy on the move Curtis (2013) wrote about having students writing and sharing through authentic activities such as asking students to document their journeys while travelling and then sharing that information with their classmates. Curtis also discussed how new questions generated from the writing and sharing helped engage students in critical thinking. According to Curtis the writing, subsequent reading, as well as the discussions generated from the subsequent questions were all examples of authentically applying literacy skills as a way of engaging children in reading activities. While Curtis was referring to working with children instead of preservice teacher the concept of authentically applying literacy skills also applies to the preservice teachers.

In studying what works for adults with limited literacy Huang (2013) indicated that if adult learners found the materials they were learning were directly applicable to their lives, then they were motivated to learn. Literacy activities that are directly applicable to their lives are authentic literacy activities. While preservice teachers are not considered to have limited literacy the concept of using authentic literacy activities to assist in promoting learning does apply.

The current study paired preservice teachers with diverse Hispanic, fourthgraders in contextualized activities which included reading by both groups and correspondence between the two groups. These authentic literacy tasks provided the 
preservice teachers with the opportunity to develop relationships with the fourth-grade students.

\section{What Preservice Teachers Have Learned and Subsequently Implemented}

Bryan and Abell (1999) were looking for answers on how the development of professional knowledge by preservice teachers is affected by their experiences while in a teacher education program. Examining preservice teachers' reading beliefs and practices Van Sluys, Laman, Legan and Lewison (2005) found that as individuals forged new understandings they also realized that they could use their new knowledge to help them when encountering new situations. Preservice teachers serving as pen pals to elementary school students learned the possibilities for high level writing when students engage in authentic writing experiences on a daily basis (Moore and Seeger 2009). Studying the influence of a university-school partnership on the literacy instruction efficacy of preservice teachers, Johnson (2010) found that preservice teachers were much more likely to use methods that they had seen in action.

\section{Measuring Changes in Preservice Teachers’ Pedagogical And Content Knowledge}

Wanting to look, among other things, at changes in preservice teachers' pedagogical and content knowledge, the purpose of Schmidt, et al's (2009/2010) study was to "develop and validate an instrument designed to measure preservice teachers' selfassessment of their Technological Pedagogical Content Knowledge (TPACK) and related knowledge domains included in the framework." (p. 129). Ultimately the work of Schmidt, et al (2009/2010) led to the Survey of Preservice Teachers' Knowledge of Teaching and Technology (SPTKTT) referenced by Abbitt (2011) as among the more 
developed tools for assessing preservice teachers' knowledge of many areas including technology and pedagogy.

\section{Reading Maturity}

The final section of the literature review is on the concept of using preservice teachers' reading maturity as an indicator of their readiness to become literacy educators. Another element in the development of preservice teachers as they work on developing their readiness to teach literacy is that of reading maturity. Thomas (2001), expanding on the work of Gray and Rogers (1956), developed the Reading Maturity Survey and has identified six elements or categories that reflect a reader's reading maturity. The six categories in the Reading Maturity Survey are "reading attitudes and interests; reading purposes; reading ability; reaction to and use of ideas to apprehend (higher-order literacy); kind of materials read; and personal adjustment to reading/transformational reading" (Thomas, 2001, p. 59-60). Discussing the use of the Reading Maturity Survey as a part of evaluating a teacher education program, Theiss, Philbrick and Jarman (20082009) questioned whether there is a relationship between preservice teachers' reading maturity and other competency measures. The current study looked at relationships between preservice teachers' results of pre-test / posttest administration of the Reading Maturity Survey because the researcher wondered if there is a connection between the two indicators as a measure of preservice teacher preparedness to teach literacy.

Theiss, Philbrick and Jarman (2008-2009) questioned whether literacy instruction affects the reading maturity of preservice teachers indicating that increased growth in 
reading maturity may lead to increased critical thinking abilities, reflection and transformed teaching practices on the part of the preservice teachers.

In looking at the topic of mentored learning to teach, Wang and Odell (2002), indicated that "Although the direct relationship between teachers' beliefs and their teaching practice is not consistently identified (Wideen, Mayer-Smith, \& Moon, 1998), research on both preservice teachers and inservice teachers suggests that their personal dispositions toward teaching have a strong impact on what they are able to learn from their professional development opportunities" (Richardson, 1996, p. 485). Based on Vygotsky's (1978) concept of the zone of proximal development's internalization / externalization process, the research of Wang and Odell (2002), and extending the concept to reading maturity, it is reasonable to use the Reading Maturity Survey as an indicator of what preservice teachers are able to learn from their professional development opportunities.

As originally indicated this chapter has included a review of the literature on defining literacy, literacy teacher education, and authentic literacy activities, improving literacy teacher education, expectations for preservice teacher training, incorporating higher level questions, the use of authentic tasks in teacher preparation, what preservice teachers have learned and subsequently implemented, measuring changes in preservice teachers' pedagogical and content knowledge, and reading maturity. This review now leads us to the purpose of this study which was to examine the effect of authentic literacy experiences as Book Buddies with Hispanic, fourth graders on preservice teachers' literacy content knowledge, and reading maturity. This study may contribute to knowledge about the effect of preservice teachers authentic literacy experiences on the 
preservice teachers' literacy content knowledge, and reading maturity. This study extended the research completed by the In2Books pen pal program Teale et al, (2007), which focused on children, to focus on preservice teachers as adult learners and Book Buddies. This study contributed to the literature on what happens when preservice teachers learn incorporating a social perspective (Vygotsky, 1978), contextualized activity and assisted learning (Englert and Palincsar, 1991), meaningful enterprise rather than learning in an abstract way (Raphael and Englert, 1989), taking into account Dickinson and Summers (2010, p. 112) findings that "learning tasks need to consider transferability into practice" as well as the Florida Educator Accomplished Practices (2011) indicators and standards for teacher preparation programs in achieving educational goals, and the findings of previously implemented effective practices.

\section{CHAPTER III}

\section{Methods}

The researcher used the procedures discussed below to investigate the effect of participating in Book Buddies, an authentic literacy experience, with Hispanic fourth graders on preservice teachers' literacy content knowledge, and reading maturity. The chapter is organized into the following sections: instrumentation, participants, research questions and hypotheses, procedures, data collection, and data analysis used in the study.

This was a quasi-experimental, pretest-posttest comparison study. It examined whether participating in Book Buddies with Hispanic fourth graders influenced preservice teachers' literacy content knowledge (LCK), and the reading maturity as 
measured by the subcategory Literacy Content Knowledge of the Survey of Preservice Teachers' Knowledge of Teaching and Technology (SPTKTT) and by the Reading Maturity Survey (RMS), respectively.

\section{Instrumentation}

The SPTKTT specifically designed for preservice teachers majoring in elementary or early childhood education and the Reading Maturity Survey were used to collect data in this study. Schmidt et al.'s (2009/2010) study to "develop and validate an instrument designed to measure preservice teachers' self-assessment of their Technological Pedagogical Content Knowledge (TPACK) and related knowledge domains included in the framework" resulted in the creation of the SPTKTT (p. 123). Having deleted problematic items after the instrument was reviewed Schmidt et al. (2009/2010) ran a new factor analysis on the revised instrument and "the resulting TPACK instrument exhibited strong internal consistency reliability" (p. 131). The updated reliability scores for internal consistency (alpha) ranged from .78 to .93 for the seven TPACK subscales (Schmidt et al., 2009/2010).

Reviewing current methods and instruments being used to measure TPACK, Abbitt (2011) stated, "the Survey of Preservice Teachers' Knowledge of Teaching and Technology is among the more mature tools designed specifically based on the TPACK framework for assessing knowledge of preservice teachers" (p. 290). Abbitt went on to say, "the survey (SPTKTT) has been demonstrated to be valid and reliable based on the work of Schmidt et al (2009/2010) and provides an efficient tool for research and evaluation relating to TPACK" (p. 291). In this study, Questions 1-46 of the Survey of 
Preservice Teachers' Knowledge of Teaching and Technology (Schmidt et al., 2009) were presented in order with categories removed. The Reading Maturity Survey (previously The Reading Survey [Thomas, 2001]) is a simple self-report survey instrument designed to assess reading maturity. The survey contains 60 questions, 10 from each of the six subcategories: reading attitudes and interests; reading purposes; reading ability; reaction to and use of ideas to apprehend higher-order literacy; kind of materials read; and personal adjustment to reading/transformational reading. Each question is answered on a 5-point Likert scale. The score for the Reading Maturity Survey, which can be treated as interval scale data, is the mean of the 60 item scores for each individual. The subcategory scores for each of the six areas of reading maturity can also be generated. Split-half reliability was calculated in an earlier study (Thomas, 2001), when it was given to 82 college students, using the six subcategory scores of the instrument. The correlation between halves was .85 and when the Spearman-Brown formula was used to estimate the reliability coefficient for the whole instrument, it was .92. It has no time limits but is estimated to take approximately 20 minutes to complete. Permission to use The Reading Maturity Survey was obtained from author Matt Thomas.

Regarding construct validity: According to Thomas (2013) "As the construct has emerged over the past 50 years, relatively few reading scholars have employed definitions or working descriptions addressing the concept of reading maturity.” (p. 148). Thomas goes on to state

Casale (1982, pp. 4-5) extrapolated the following definition from Gray and Rogers (1956), the "chief populists of the term:" Reading maturity is a state of 
reading ability typically reached in adult life as a product of overall development, instruction, experience, and years of extensive reading. Its chief features are accurate, high-level comprehension, objective thinking, and the ability to speak back fluently and analytically that which has been read with little or no prompting. (pp 148-149)

Using the set of subcategories identified by Gray and Rogers (1956) and influenced by the works of others including Casale and Manzo, in 2001 Thomas identified the following "six categories of reading maturity: reading attitudes and interests; reading purposes; reading ability; reaction to and use of ideas to apprehend (higher-order-literacy); kind of materials read; and personal adjustment to reading/transformational reading" (Thomas, 2001, p. 150)

On the topic of "How can progress toward reading maturity be measured or monitored?" Thomas (2013) stated that the construct of reading maturity is still in the process of being defined and references the work of Casale (1982). Casale's work (as cited in Thomas, 2013, p. 152) states the classic paradox of not adequately measuring a construct for lack of construct definition, and not defining a construct for lack of adequate measurement, have challenged efforts to define and measure reading maturity.

Thomas' (2001) Reading Maturity Survey and (2013) “working description of the reading maturity construct" (p. 157) that includes the six aforementioned categories of reading maturity are a step in the right direction towards addressing the current situation of a lack of specific construct validity due to a lack of construct definition. 


\section{Participants}

\section{Preservice Teacher Participants}

The participants, and focus of the study, were obtained using criterion sampling. The sample was made up of non-probabilistic convenience groups, 43 ( $n=33$ experimental, $n=10$ comparison) undergraduate preservice teachers (PSTs) who were enrolled in the third of four required reading education courses in their programs at a state research university in the southeastern part of the United States. Preservice teachers chose to be in the experimental or comparison group based on the opportunity to earn extra credit points $($ experimental $=30$ points, comparison $=15)$. Preservice teachers in both the experimental and control groups received the same coursework and instruction from their professors.

\section{Fourth Grade Student Participants}

Two pre-existing classes each of 19 fourth-grade students in a large public school district in the same area as the university, the researcher's students and another fourth grade class, were participants. The fourth grade student participants were all Hispanic, fourth-grade students whose native language is Spanish as verified by the Miami-Dade County Public Schools “Home Language Survey”, Form FM-5196ESH Rev. (09-09) completed by parents at registration and maintained in school records. All of the fourth graders were at a low socio-economic status (SES) as determined by their free and reduced lunch application status based on school records. 
No data were collected from the fourth-grade students. There were no control or experimental groups for the fourth grade students because they were not the focus of the

study. The training received by the students in order to participate in this study consisted of reviewing the friendly letter format, reminders to read their books and letters carefully as well as reminders to answer the questions received from their preservice teachers as thoroughly as possible.

\section{Research Questions and Hypotheses}

Question 1: Do preservice teachers who have engaged with authentic literacy experiences with Hispanic fourth graders as Book Buddies exhibit higher mean adjusted scores on the subcategory Literacy Content Knowledge (LCK) than preservice teachers who do not experience being Book Buddies? Hypothesis 1: Preservice teachers who have authentic literacy experiences with Hispanic fourth graders as Book Buddies will exhibit higher mean adjusted scores on the Literacy Content Knowledge (LCK) subcategory of the Survey of Preservice Teachers' Knowledge of Teaching and Technology (SPTKTT) posttest than preservice teachers who do not experience being Book Buddies when controlling for the SPTKTT pretest.

Question 2: Do preservice teachers who have engaged with authentic literacy experiences with Hispanic fourth graders as Book Buddies exhibit higher mean adjusted scores on the Reading Maturity Survey (RMS) than preservice teachers who do not experience being Book Buddies? Hypothesis 2: Preservice teachers who have authentic literacy experiences with Hispanic fourth graders as Book Buddies will exhibit higher 
mean adjusted scores on the Reading Maturity Survey (RMS) than preservice teachers who do not experience being Book Buddies as measured by the RMS posttest when controlling for the RMS pretest.

\section{Procedures}

\section{Procedures for the Experimental Group}

Pretest/ posttests of SPTKTT and the RMS were given before and after the treatment of the study to the preservice teachers in the experimental Book Buddies group. Information from the SPTKTT pretest- posttest was used to determine changes in preservice teachers' literacy content knowledge. Information from the Reading Maturity survey pretest-posttest was used to determine changes in reading maturity.

Preservice teachers in the experimental group wrote a letter of introduction to students using the friendly letter sample provided to them by the researcher, received a letter of introduction from the student, read the four selected books, three narrative and one informational text (see Appendix D for a list of book titles and authors) and corresponded about the books with the student via electronic mail. A total of four books, three narrative and one informational text, provided by the researcher; were read and a total of five letters per participating preservice teacher were exchanged as a part of the study. (See Appendix E for the Preservice Teachers as Book Buddies Timeline for additional information.)

The researcher provided the experimental group of preservice teachers with a set of question stems (see Appendix F for the new revised upper levels of Bloom's 
Taxonomy) analyzing, evaluating and creating to use as support when creating higher order open-ended comprehension questions. The experimental group included higher order, open-ended comprehension questions in their book related letters to the fourth grade students. The added practice of creating higher order open-ended comprehension questions as a part of an authentic literacy experience with the fourth graders provided preservice teachers with authentic practice and reasons for creating higher order comprehension questions. In addition later being able to see first-hand how the fourth graders responded to their questions also gave the preservice teachers authentic examples of how the fourth graders had understood and responded to their questions. Both the creating of the questions and the reading of the responses to the questions provided the experimental group of preservice teachers with additional opportunities to further develop their literacy content knowledge as well as giving them a glimpse of the fourth graders reading maturity. The preservice teachers' reflections and comparisons of the responses could in turn also lead to increased reading maturity as they internalize the process of creating higher order comprehension questions and seeing first-hand what the responses to those questions were.

\section{Procedures for the Comparison Group}

Pretest/ posttests of SPTKTT and the RMS were given before and after the study to the preservice teachers in the comparison group. Information from the SPTKTT pretest- posttest was used to determine changes in preservice teachers' literacy content knowledge. Information from the Reading Maturity survey pretest-posttest was used to 
determine changes in reading maturity. (See Appendix E for the Preservice Teachers as Book Buddies Timeline for additional information.)

\section{Steps for Reviewing Letters from Preservice Teachers to Fourth Graders}

The process for reviewing letters from the preservice teachers to the fourth graders consisted of the following steps: The researcher checked incoming emails for letters from preservice teachers to fourth graders. The researcher then opened emailed letter(s) from preservice teachers. The letters were reviewed twice by the researcher: The first time for ethical appropriateness and the second time for connections to the text.

The steps for reviewing for ethical appropriateness by the researcher consisted of the following steps: Read the letter to determine ethical appropriateness. The review for ethical appropriateness consisted of reading the letter to verify that the preservice teacher had not included contact information such as a phone number, email or any other way that the preservice teacher and the fourth graders could establish direct contact. Any personal information shared was on the level of what it would be appropriate for any teacher, preservice or otherwise, to share with a student. Appropriate information was considered to be at the level of what was indicated in the suggested friendly letter: First name, hobbies, pets, etc. Inappropriate information would include personal contact information, inappropriate / offensive language, personal details about the preservice teacher's life that would not be considered appropriate to share with a fourth grader. Any questions to the fourth grader of a personal / intimate nature would also have been considered inappropriate. 
The letters from the preservice teachers to the fourth graders were then reviewed a second time. The second review was a review for connections to the text. The review of letters for connections to the text consisted of the following steps: Read the letter to confirm that the book that was indicated as being the one written about was actually the book that was being written about. The researcher had read all of the books included in the research project to be familiar with the material in question. The researcher verified that the letter included references to the text referenced in the subject and that the letters included higher order thinking skills questions for the fourth graders to respond to.

Any letters from preservice teachers to fourth grade students that did not meet the review criteria for ethical appropriateness and for connections to the text were returned to the preservice teacher for revision. In the case of the preservice teacher including their last name on the letter, which was the most common item, the researcher removed the last name from the letter before printing it and reminded the preservice teacher to not include their last name.

Once the researcher completed the review for ethical appropriateness and connections to the text the researcher logged the information in on the researcher's log documenting that the preservice teacher's letter had been received and reviewed. The researcher then printed and prepared to distribute the letter to the fourth grade student.

\section{Distribution of Preservice Teachers' Letters to Fourth Graders}

The researcher and the second classroom teacher participating, a recent doctoral graduate herself, distributed the letters to the fourth grade students. The researcher and 
the second classroom teacher distributed the letters to their respective fourth graders and answered any questions posed by the fourth graders. Fourth graders were also provided assistance in reading the letter when necessary as indicated by the fourth grader.

\section{Reviewing Letters from Fourth Graders to Preservice Teachers}

The process for reviewing letters from the fourth graders to the preservice teachers consisted of the following steps: The letters were reviewed twice by the researcher: For ethical appropriateness and for connections to the text.

The steps for the researcher's review for ethical appropriateness consisted of the following: The researcher read the letter to determine ethical appropriateness. The review for ethical appropriateness consisted of reading the letter to verify that the fourth grader had not included contact information such as a phone number, email or any other way that the fourth grader and the preservice teacher could establish direct contact. Any personal information shared was on the level of what it would be appropriate for any student, to share with a teacher, preservice or otherwise. Appropriate information was considered to be at the level of what was indicated in the suggested friendly letter: First name, hobbies, pets, etc. Inappropriate information would include personal contact information, inappropriate / offensive language, and personal details about the fourth grader's life that would not be considered appropriate to share with any teacher. Any questions to the preservice teacher of a personal / intimate nature would also have been considered inappropriate. Any letters from the fourth grade students to the preservice teachers that did not meet the review criteria for ethical appropriateness were returned to 
the fourth grade student for revision after the researcher reviewed appropriate procedures and clarified any misunderstandings on the part of the fourth graders.

The letters from the fourth graders to the preservice teachers were then reviewed a second time by the researcher. The second review was a review for connections to the text. The review of letters for connections to the text consisted of the following steps: The researcher read the letter to confirm that the book that was indicated as being the one written about was actually the book that was being written about. The researcher had read all of the books included in the research project to be familiar with the material in question.

The researcher verified that the letter included connections and references to the text referenced in the letter. In doing so the researcher looked for responses to the higher order thinking skills questions from the preservice teachers. The fourth graders were encouraged, but not required to go back and add additional information and responses in their letters. The reason for this was so that the preservice teachers would have authentic literacy experiences by being able to see exactly what the students had written. This way the preservice teachers would get an authentic record of their fourth grade student's understanding and interpretation of the preservice teacher's questions. The scanned responses also gave preservice teachers authentic insight into their fourth grade student's writing and communication skills.

The researcher provided oral feedback to the students regarding their letters and responses. The researcher met with students individually, or in groups if the students 
preferred a group setting and conferenced with them about their answers. This way the fourth grade students had feedback about their work.

Once the researcher completed the review for ethical appropriateness and connections to the text the researcher logged the information in on the researcher's log indicating that the student had responded to the text. The researcher then scanned the fourth grade student's letter and forwarded it by email to their preservice teacher.

Preservice teachers were permitted to respond to the students' response letters. At the conclusion of the study posttests of SPTKTT and the RMS were given to preservice teachers in the experimental group. See Appendix E for the Preservice Teachers as Book Buddies Timeline for additional information. See Appendix G for sample letters between preservice teachers and fourth graders.

\section{Data Collection}

Pretest/ posttests of SPTKTT and the RMS were given before and after the treatment of the study to the preservice teachers in both groups, experimental Book Buddies and the comparison group. Information from the SPTKTT pretest- posttest was used determine changes in preservice teachers' literacy content knowledge. Information from the Reading Maturity survey pretest-posttest was used to determine changes in reading maturity. 


\section{Data Analysis}

A series of analyses of covariance (ANCOVA; McNeil, Newman, \& Kelly, 1996) were used to determine whether there were significant differences in the dependent variables between the experimental and comparison groups. This quasi-experimental study applied ANCOVA in testing the two hypotheses. Using the appropriate pretest scores as covariates for adjusting the posttest means of the subcategories LCK, of the SPTKTT and of the RMS the mean adjusted posttest scores from the experimental group and comparison group were compared. A significance level of $p<.05$ was set a priori. The statistical analyses of all of the collected data were compared utilizing the Statistical Package for the Social Sciences $21^{\text {st }}$ edition (SPSS).

\section{Summary}

In summary this chapter explained the instrumentation, participants, research questions and hypotheses, procedures, data collection and data analysis used in the study.

\section{CHAPTER IV}

\section{RESULTS}

This chapter presents the hypothesis test results for each research hypothesis from this study and the demographics of the participants. The results of each question and hypothesis are presented in the order that they were stated and a summary of research findings concludes the chapter. 


\section{Sample Demographics}

There were 43 preservice teachers ( $n=33$ experimental, $n=10$ comparison) who completed all parts of the data collection procedures. Demographic information of this sample is presented in Table 1.

Thirty-seven of the 38 experimental group preservice teachers established contact, by means of a letter, with their book buddie. Of the 37 who initiated contact, three preservice teachers ended up dropping the course and did not complete the project. A fourth preservice teacher chose to change her participation to the comparison group instead. Overall, 33 of 38 initial members of the experimental group completed the study and took the SPTKTT and the RMS posttests after having participated in multiple authentic literacy experiences as Book Buddies with Hispanic fourth graders. Of the 10 preservice teachers who initially signed up for the comparison group, two ended up dropping the course and did not complete the project. Two preservice teachers changed their initial participation from experimental group to comparison group so ultimately 10 preservice teachers ended up participating in the comparison group.

Table 1 Study Participants Demographics based on the Survey of Preservice Teachers' Knowledge of Teaching and Technology (SPTKTT) Pretests

\begin{tabular}{lcr}
\hline Demographic & $\begin{array}{l}\text { Treatment } \\
\text { Group } \\
n=33\end{array}$ & $\begin{array}{l}\text { Comparis } \\
\text { Group } \\
n=10\end{array}$ \\
Sex & & \\
$\quad$ Men & 2 & 1 \\
$\quad$ Women & 31 & 9 \\
Age Range & &
\end{tabular}


Major

Elementary Education

Other

No response

Area of Specialization

Early Childhood Ed. w/Special Ed

English \& Language Arts

Health

Instructional Strategist: Mild/Moderate (K8)

Endorsement

Mathematics

Science - Basic

Other : Multiple areas of specialization

13

52

$\begin{array}{ll}1 & - \\ 3 & 1\end{array}$

Educational Computing Minor

Undergraduate Status

Sophomore

Junior

Senior

The information contained in Table 1 comes from the preservice teachers' responses to the demographics section of the Survey of Preservice Teachers' Knowledge of Teaching and Technology (SPTKTT) Pretests. The demographics section of the SPTKTT included the following categories: the sex, age range, major, area of specialization, educational computing minor and undergraduate status of the preservice teachers.

\section{Tests of Hypotheses}

Table 2 presents the means and standard deviations of the pretest and posttest scores of the individual dependent variables as well as those of the posttest scores adjusted by the pretest scores in the ANCOVA of the participants in the experimental and 
comparison groups. The dependent variables were literacy content knowledge, and reading maturity.

Literacy content knowledge as defined by this researcher is having knowledge about literacy, using a literary way of thinking and knowing different ways and strategies of developing ones understanding of literacy.

Reading Maturity is defined by the six categories of The Reading Maturity Survey. The six subcategories are: reading attitudes and interests; reading purposes; reading ability; reaction to and use of ideas to apprehend higher-order literacy; kind of materials read; and personal adjustment to reading/transformational reading. (Thomas, 2001).

For this study the researcher has selected the implicit definition of literacy presented by Cunningham (2000) that consists of three parts "(a) the ability to engage in some of the unique aspects of reading and writing, (b) contextualization to some extent within the broad demands of the society, and (c) some minimal level of practical proficiency" (p. 64).

Referring to reading maturity Thomas (2013) stated

Casale (1982, pp. 4-5) extrapolated the following definition from Gray and Rogers (1956), the "chief populists of the term:" Reading maturity is a state of reading ability typically reached in adult life as a product of overall development, instruction, experience, and years of extensive reading. Its chief features are 
accurate, high-level comprehension, objective thinking, and the ability to speak back fluently and analytically that which has been read with little or no prompting. (pp 148-149)

Table 2

Pretest, Posttest, and Adjusted Posttest Scores and Standard Deviations as a Function of Group Membership

\begin{tabular}{|c|c|c|c|c|c|c|c|c|}
\hline \multirow[b]{2}{*}{ Source } & \multicolumn{3}{|c|}{ Pretest } & \multicolumn{3}{|c|}{ Posttest } & \multicolumn{2}{|c|}{$\begin{array}{l}\text { Posttest Value } \\
\text { Adjusted by the } \\
\text { Covariate } \\
\text { (pretest) }\end{array}$} \\
\hline & $M$ & $S D$ & $S E^{*}$ & $M$ & $S D$ & $S E^{*}$ & $M$ & $S E^{*}$ \\
\hline LCK & & & & & & & & \\
\hline & 13.15 & 1.87 & .33 & 13.06 & 1.68 & .25 & 13.03 & .25 \\
\hline & 12.90 & 2.28 & .72 & 13.30 & 1.49 & .46 & 13.38 & .46 \\
\hline $\begin{array}{l}\text { Comparison } \\
\text { RMS }\end{array}$ & & & & & & & & \\
\hline & 253.97 & 28.7 & 5.00 & 265.85 & 28.72 & 2.85 & 264.2 & 2.85 \\
\hline Comparison & 245.90 & 41.68 & 13.18 & 248.40 & 42.68 & 5.20 & 253.82 & 5.20 \\
\hline
\end{tabular}

Note. *Standard error is used since these are estimated values. LCK stands for Literacy Content Knowledge, and RMS stands for Reading Maturity Survey.

There were two research questions in this study. The following are the research questions, hypotheses and results for each of the research questions.

\section{Research Question 1}

Do preservice teachers who have engaged with authentic literacy experiences with Hispanic, fourth graders as Book Buddies exhibit higher mean scores on the subcategory Literacy Content Knowledge (LCK) as compared to preservice teachers who do not experience being Book Buddies? 
Using SPSS Statistics 21 (2012), an analysis of covariance was carried out testing the null hypothesis that there was no difference between the means scores on the LCK posttest adjusted by the LCK pretest score between preservice teachers who participated in the reading buddies activity and those who did not. Table 3 is the source table for this statistical test.

Table 3

Analysis of Covariance of Literacy Content Knowledge as a Function of Using Book Buddies

\begin{tabular}{lrrrrrr}
\hline Source & $d f$ & \multicolumn{1}{c}{ SS } & \multicolumn{1}{c}{ MS } & \multicolumn{1}{l}{ F } & \multicolumn{1}{c}{$p$} & $\eta^{2}$ \\
\hline LCK pretest & 1 & 26.546 & 26.546 & 12.727 & .001 & .241 \\
Treatment & 1 & .896 & .896 & .429 & .516 & \\
(T) & & & & & & \\
Error & 40 & 83.433 & 2.086 & & \\
$\quad$ Total & 42 & 110.419 & & & & \\
\hline
\end{tabular}

No significant differences were found on the dependent variable LCK using the .05 level of significance. The null hypothesis was not rejected.

Hypothesis 1: Preservice teachers who have authentic literacy experiences with Hispanic fourth graders as Book Buddies will exhibit higher mean adjusted scores on the Literacy Content Knowledge (LCK) subcategory of the Survey of Preservice Teachers' Knowledge of Teaching and Technology (SPTKTT) posttest than preservice teachers who do not experience being Book Buddies when controlling for the SPTKTT pretest could not be accepted. Next we go to research question number 2 .

\section{Research Question 2}

Do preservice teachers who have engaged with authentic literacy experiences with Hispanic fourth graders as Book Buddies exhibit higher mean scores on the Reading 
Maturity Survey (RMS) as compared to preservice teachers who do not experience being Book Buddies?

An analysis of covariance was carried out testing the null hypothesis that there was no difference between the means scores on the RMS posttest adjusted by the RMS pretest score between preservice teachers who participated in the reading buddies activity and those who did not. Table 4 is the source table for this statistical test.

Table 4 Analysis of Covariance of Reading Maturity as a Function of Using Book Buddies

\begin{tabular}{lcccccc}
\hline Source & $d f$ & $S S$ & $M S$ & $F$ & $P$ & $\eta^{2}$ \\
\hline RMS pretest & 1 & $32,107.144$ & $32,107.144$ & 120.032 & .000 & .750 \\
Treatment (T) & 1 & 819.101 & 819.101 & 3.062 & .044 & .071 \\
Error & 40 & $10,699.499$ & 267.487 & & & \\
$\quad$ Total & 42 & $45,143.116$ & & & & \\
\hline
\end{tabular}

Significant differences were found on Reading Maturity using the .05 level of significance. The null hypothesis was rejected. The difference was very small however since only .07 of the difference was due to the treatment.

Based on the above results Hypothesis 2: Preservice teachers who have authentic literacy experiences with Hispanic fourth graders as Book Buddies will exhibit higher mean adjusted scores on the Reading Maturity Survey (RMS) than preservice teachers who do not experience being Book Buddies as measured by the RMS posttest when controlling for the RMS pretest was accepted.

\section{Conclusion}

A series of analyses of covariance (ANCOVA; McNeil, Newman, \& Kelly, 1996) were used to determine whether there are significant differences in the means of posttreatment scores of experimental and control groups of the Literacy Content Knowledge 
(LCK), of the SPTKTT, and Reading Maturity when the posttest scores were adjusted using the analogous pretest scores. Significant differences between adjusted group means were not found on any of the dependent variables using the .05 level of significance for the Literacy Content Knowledge (LCK), of the SPTKTT. Significant differences between adjusted group means were found on the dependent variable using the .05 level of significance for Reading Maturity. The difference was very small however since only $.07 \%$ of the variance was due to the treatment. 


\section{CHAPTER V}

\section{DISCUSSION}

The purpose of this chapter is to integrate the results of this study with existing theory and research by discussing the results of the study, sharing the researcher's conclusions about the research findings as they relate to the literature review, identifying implications of the study, suggesting recommendations and providing a conclusion. The chapter is organized by sections and connects back to previous sections of the dissertation. The sections are purpose of the study, findings, discussion of results, limitations and recommendations for future research.

\section{Purpose of the Study}

The purpose of this study was to examine the effect of authentic literacy experiences as Book Buddies with Hispanic, fourth graders on preservice teachers' literacy content knowledge and reading maturity. The work of Purcell-Gates, Degener, Jacobson and Soler (2002), which discussed the topic of the research base on authenticity and its positive effects on adult learners, led to the research questions asked in this dissertation project. Their work also provided the operational definition of authentic literacy activities used in this study.

Other researchers also influenced the conceptualization of this study. One was Theiss et al. (2008-2009) whose work focused on the relationship between preservice teachers' reading maturity (a self-report on one's reading attitudes and habits) and their disposition to teach reading. Another researcher, Abbitt (2011), discussed tools for assessing preservice teachers' knowledge in many areas including technology and 
pedagogy. He emphasized the need for educators to measure preservice teachers' readiness to teach. These, along with others, provided the framework for the study.

\section{Findings}

The findings for Question 1 were that preservice teachers who have authentic literacy experiences with Hispanic, fourth graders as Book Buddies did not exhibit higher mean scores on the subcategory Literacy Content Knowledge (LCK) on the Survey of Preservice Teachers' Knowledge of Teaching and Technology (SPTKTT) posttest than preservice teachers who did not experience being Book Buddies when controlling for the SPTKTT pretest. No significant differences between adjusted group means were found on the dependent variable using the .05 level of significance for literacy content knowledge.

The findings for Question 2 were that preservice teachers who have authentic literacy experiences with Hispanic fourth graders as Book Buddies exhibited higher mean scores on the Reading Maturity Survey (RMS) than preservice teachers who do not experience being Book Buddies as measured by the RMS posttest when controlling for the RMS pretest. Significant differences between adjusted group means were found on the dependent variable using the .05 level of significance for Reading Maturity. The difference was very small, however since only $.07 \%$ of the variance was due to the treatment.

\section{Discussion of Results}

This study was designed from a sociocultural perspective, (Vygotsky, 1978), that individuals learn best from contextualized experiences. The contextualized experiences in the study were reading and writing to a real reader and writer, the Hispanic fourth 
graders which replicated real life communication. Given that the results were not significant for Literacy Content Knowledge, there are several aspects that need to be considered. These aspects include the issue of sample size, the instrumentation that was used, the preparation of the preservice teachers based on the two previous reading courses, the methodology, duration of the study, and the literacy constructs the researcher was hoping the preservice teachers would develop.

\section{Sample Size}

The study informs the field of reading research that a larger sample of preservice teaches is needed to determine if the procedures used in the study would have an effect on preservice teachers. The sample size in the current study was insufficient because to get a power of .8 would have required a minimum of 37 subjects in each group. A power analysis tells us that to obtain a power of .80 at alpha $=.05$ with a medium effect size, we would need at least 128 participants. This is a minimum value. If you do not have equal group sizes the required $\mathrm{N}$ would actually be larger. Therefore future studies should have at least 128 participants.

\section{Instrumentation}

Another aspect that needs to be taken into consideration in the results is that of the instrumentation that was used in the study. The questions that were used to gather responses for the Literacy Content Knowledge (LCK) section of the research study came from a subsection of the Survey of Preservice Teachers’ Knowledge of Teaching and Technology (SPTKTT). These questions however only constituted a small subset that of literacy content knowledge, from the overall SPTKTT. In retrospect another instrument 
that had been specifically designed to measure literacy content knowledge as the main focus of the research may have provided a more detailed and accurate reflection of the initial levels of literacy content knowledge and of the changes, if any, in that literacy content knowledge after the treatment. By using such a limited set of questions it was not possible to gather the richness of detail that the topic actually needs to be properly addressed. In addition the SPTKTT is set up in a Likert Scale format with the participants self-reporting on their responses. The researcher notes that this is not in any way a negative reflection on the Survey of Preservice Teachers' Knowledge of Teaching and Technology instrument which has been tested and found to have both content and construct validity and reliability and when used in its entirety should present an accurate reflection of what it was intended to measure.

What the researcher intended to measure is not what the Survey of Preservice Teachers' Knowledge of Teaching and Technology was developed to measure. For the purposes of what the researcher was attempting to measure a more open ended format might have done a better job of capturing both initial levels and subsequent changes, if any, in literacy content knowledge. At this time the researcher is not familiar with such an instrument but it would be beneficial to do additional research to see if such an instrument is available before repeating this research study on a larger scale.

\section{The Preparation of the Preservice Teachers Based on the Two Previous Reading Courses}

Another factor that should be taken into consideration is the preparation of the preservice teachers based on the two previous reading courses. Since the preservice 
teachers that participated in the current study had already completed two previous reading courses, it could be argued that they already had rather extensive literacy content knowledge. If they already had extensive literacy content knowledge from their two previous courses, then it may have taken a much richer set of experiences, beyond the scope of this research study, to significantly impact the preservice teachers' level of literacy content knowledge in their third reading course and this study to further enhance their literacy content knowledge. This is an aspect that should be taken into consideration for future studies as a part of preservice teachers' initial reading preparation.

\section{Methodology in Terms of the Results}

In terms of the methodology that was used, the format followed the basic format of the In2Books research project by Teale and Gambrell (2007). Specifically, the students and, in this case, preservice teachers exchanged letters related to the books they had all read with the researcher acting as the reviewer / filter before either group, preservice teachers or Hispanic fourth graders seeing what the other had written. The way the In2Books project was implemented when the researcher participated in it with her previous students was there were a total of five books which were read and a set of six letters (one introductory letter and five letters related to books) written and responded to over the course of an entire school year. As a part of the In2Books program students' letters were reviewed by the teacher and students were required to go back, edit and revise their letters after feedback from the teacher until they had addressed all of the 
questions asked by their In2Books pen pal. The focus of the In2Books program was on the students, not the adult pen pals.

In the current study however a total of four books were read and a set of five, one introductory letter and four book-related letters, were written over a twelve week period. A set of letters refers to the preservice teachers writing a letter and the Hispanic fourth grader responding to that letter.

As with the In2Books program the researcher personally read and reviewed each letter before the intended recipients, preservice teachers and / or fourth grade students, actually saw it. The letters from the preservice teachers were reviewed for ethical appropriateness and for connections to the text as was also done in the In2Books program. Letters from the students were all reviewed for ethical appropriateness.

In terms of connections to the text for the letters from the students, the procedures used in this study varied in that students, although encouraged, were not required to go back and make any corrections / adjustments to their letters. The reason for this was because the preservice teachers as a part of their authentic literacy experience were supposed to receive authentic letters so that they could see what the students were actually creating themselves without help from a more knowledgeable other, the teacher / researcher. This process also allowed the preservice teachers to see how their book buddies had interpreted their higher order thinking skills questions. In order to maintain authenticity, students were not required to revise their letters to the preservice teachers. 


\section{Duration of the Study}

In terms of the duration of the study it could be that the twelve week length of the study was insufficient to generate a significant change in the preservice teachers' literacy content knowledge. It could be that if more time had been allowed per book and set of letters, the preservice teachers would have had more time to craft even more carefullyconstructed higher order thinking questions for their fourth grade book buddies to respond to. The same could be said for the fourth graders, if they had been allowed more time to read their books and letters and then write their responses, the results might have been richer in content and quality of responses. If the study were to be repeated, it might be beneficial to conduct any future studies over a longer period of time such as several semesters.

\section{Literacy Constructs the Researcher was Hoping the Preservice Teachers Would Develop}

In terms of the literacy constructs that the researcher was hoping that the preservice teachers would develop in retrospect there was not enough in the letterexchanges for there to have been a noticeable impact on literacy content knowledge, or reading maturity. The preservice teachers were provided question stems with the higher levels of Bloom's taxonomy so that they could use them to assist them in creating higher thinking skills questions for their fourth grade book buddies. There was however no actual instruction provided to the preservice teachers by the researcher regarding the importance of creating and using higher order thinking questions with students. They also had no formal opportunity to ask the researcher and or discuss any questions they may have had regarding creating higher order thinking skills questions. In addition in 
terms of the authentic letters that they received from their fourth grade book buddies there were no formal discussions where the letters could be discussed in terms of connections to the text, responses to the higher order thinking skills questions or even evaluated on any sort of rubric.

For this study the researcher selected the implicit definition of literacy presented by Cunningham (2000) that consists of three parts "(a) the ability to engage in some of the unique aspects of reading and writing, (b) contextualization to some extent within the broad demands of the society, and (c) some minimal level of practical proficiency" (p. 64).

In terms of Cunningham's implicit definition of literacy the preservice teachers did participate in literacy experiences in the process of reading and writing for contextualized purposes with at least a minimal level of practical proficiency.

Based on Duke et al's (2006) operational definition of authentic literacy and this researcher's definition of authentic literacy tasks, the preservice teachers did engage in authentic literacy activities with their fourth grade book buddies. Based on the results however it would appear that engaging in authentic literacy tasks without the benefit of specific instruction and discussion related to those authentic literacy tasks does not have a significant impact on literacy content knowledge as evidenced by the results.

In conclusion in terms of the preservice teachers' reading maturity, the authentic literacy activities appear to have only had a very minimal impact. Based on these results it again appears that engaging in authentic literacy tasks without the benefit of specific instruction and discussion related to those authentic literacy tasks will only minimally impact the literacy construct of reading maturity. 


\section{Limitations}

There was one limitation for this study. The one limitation was that the numbers of preservice teachers enrolled in the reading courses was limited to the number of preservice teachers meeting the condition of taking the third of four required reading classes at any one time. This was lower than anticipated due to unknown reasons. Three sections of the reading class were offered during the term the study was conducted. Every preservice teacher in all three sections of the class participated. All pre-service teachers in all three sections were pre-and post-tested. The preservice teachers that did not volunteer to be in the experimental group were assigned to the control group. Even with participation in the study from all three groups of preservice teachers, the sample size was insufficient because to get a power of .8 would have required a minimum of 37 subjects in each group. A power analysis tells us that to obtain a power of .80 at alpha $=.05$ with a medium effect size we would need at least 128 participants. This is a minimum value. If you do not have equal group sizes the required $\mathrm{N}$ would actually be larger.

Significant differences were found on the reading maturity dependent variable using the .05 level of significance. The study however lacked statistical power due to the small sample size. Considering the importance of having all preservice teachers become effective reading teachers and literacy educators in general, there would be value in replicating the study with a larger group of participants which leads to recommendations for future research. 


\section{Recommendations for Future Research}

The researcher recommends conducting this study with the following changes to the study itself. The recommendations for future research include a larger group of participants, including discussion about the authentic literacy experiences, duration of the study, a change in instrumentation used for one of the instruments and how it would be used.

\section{A Larger Group of Participants}

The researcher recommends conducting the study again with a larger group of participants. A power analysis tells us that to obtain a power of .80 at alpha $=.05$ with a medium effect size we would need at least 128 participants. This is a minimum value. If you do not have equal group sizes the required $\mathrm{N}$ would actually be larger. So to ascertain that any future study would have statistical power a larger sample size is necessary.

A larger group of participants could be achieved by implementing the study across multiple terms. In terms of fourth grade student book buddies the additional preservice teacher participants would require additional book buddies. The need for additional book buddies might be addressed by establishing connections and making arrangements for additional teachers in the grade level to participate with their classes. In the case of multiple semesters different classes at the same school could participate as a way of having additional fourth graders to serve as book buddies. 


\section{Including Discussion in the Authentic Literacy Experiences}

In the future the researcher hopes to work with graduate or undergraduate students to engage them in authentic experiences to develop their teaching skills. In implementing future authentic experience opportunities for preservice teachers, the researcher also recommends that discussion with the preservice teachers about the authentic literacy exchanges be included as a part of future studies. The current study lacked the built-in procedures of discussion with the preservice teachers regarding their authentic literacy experiences with the fourth graders.

The rationale for including a discussion aspect is that several preservice teachers notified the researcher that in addition to reading their own letters from their book buddies they had on occasion shared the fourth graders' responses with other preservice teachers they knew in both the experimental and control groups. Some preservice teachers reported that, as they shared, they also compared students' responses, discussing a variety of aspects including levels of writing and understanding or lack thereof of the questions that had been posed. Some preservice teachers reported being excited about being able to read and compare authentic student responses, both those of their book buddies and those of their classmates' book buddies. On occasion some preservice teachers indicated to the researcher that they had been able to learn a lot about their students, particularly their academic levels, based on the responses included in the book buddies' letters. 
Writing the higher order thinking skills questions and having the opportunity to see the students' responses allowed preservice teachers to have authentic literacy experiences by seeing and also comparing authentic children's responses. This gave them insight into how children think. Based on the additional comments provided to the researcher by some preservice teachers, some of them benefitted from having had authentic literacy experiences with Hispanic fourth graders by seeing authentic student responses to their higher order thinking questions and from sharing and discussing those responses with their classmates.

For future studies the researcher, based on the comments received from some preservice teachers, suggests building in and formalizing the discussion aspect of the responses from the students so structured discussions can take place with preservice teachers. In this way the literacy constructs, literacy content knowledge and reading maturity, that the researcher had hoped to develop in the preservice teachers could be formally addressed as discussions and interactions about the students' letters occur between the preservice teachers and their professors. This process would allow the preservice teachers to analyze and reflect in a structured, guided approach that could potentially lead to increased literacy content knowledge and reading maturity as they analyze and discuss not only their own authentic literacy experiences but also those of their fellow participants. Future studies could be mixed methods to include a qualitative aspect regarding the format, aspects, and results of the discussions that would take place when including formalized discussions. 


\section{A Change in Instrumentation for a Separate but Related Study}

The researcher recommends discontinuing the use of The Survey of Preservice Teachers' Knowledge of Teaching and Technology (SPTKTT) because as previously indicated it was not intended to measure what the researcher was trying to measure. The researcher instead recommends consideration of the use of Applegate and Applegate's (2004) Literacy Habits Questionnaire which was developed while studying the reading habits and attitudes of elementary preservice teachers. Having conducted two separate studies and finding large percentages of what they termed "unenthusiastic readers" in their preservice teacher study participants Applegate and Applegate (2004) began to refer to what they call the "Peter Effect as the condition characterizing those teachers who are charged with conveying to their students an enthusiasm for reading that they do not have." (p. 556).

Based on the information the researcher has obtained about the Literacy Habits Questionnaire the researcher would have used that instrument for the current study if the researcher had been aware of its existence when the current study began. Having just recently become aware of its existence the researcher recommends its use in future studies such as the one that was carried out in this research project.

As one of several ways of addressing the situation of the unenthusiastic preservice teacher readers that they found in their studies, Applegate and Applegate (2004) indicate that institutions preparing preservice teachers have an obligation to provide them with “experiences and models that will promote their own engagement in reading." (p. 562). 
Based on the observations made by some of the preservice teacher participants to the researcher in the current study engaging in authentic literacy experiences with their book buddies was an experience that promoted their own engagement in reading.

The researcher also recommends a possible future research study using the Literacy Habits Questionnaire (LHQ) (Applegate and Applegate, 2004) in conjunction with the updated Reading Maturity Survey (Thomas 2001, 2007, 2011). The updated survey includes a Next Steps Planning form which encourages the user to begin taking the next steps in working towards reading maturity.

The researcher recommends using the Reading Maturity Survey With Next Steps Planning (RMS - NSP) and the Literacy Habits Questionnaire (LHQ), independently as a way of identifying possible gaps in preservice teachers literacy habits and reading maturity. Keeping in mind Applegate and Applegate's (2004 and 2014) recommendations for promoting engagement in reading and Thomas' (2013) suggestion that teacher education courses "in literacy education should discuss the importance of teaching toward reading maturity rather than only to avoid illiteracy.” (p.155) and that "mature reader profiles...should be the highest goal of literacy education" (p. 155).

Preservice teachers could complete the RMS -NSP and the LHQ at the beginning and at the end of their first, or any, required reading course. The group results would give professors an indication of their students' areas of strength as well as areas of need. At that point the professors using their knowledge of the content of the four required reading courses so as not to unnecessarily duplicate instruction, the professors could identify their preservice teachers' areas of need. Having identified areas of need the 
professors can make a decision as to what the best course of action would be to assist their preservice teacher students in becoming even more effective literacy educators. Another option would be using the Reading Maturity Survey With Next Step Planning (Thomas, 2013) as an ongoing class assignment placing some of the responsibility of working through the process on the preservice teachers.

\section{Conclusion}

This chapter integrated the results of this study with existing theory and research by discussing the results of the study, sharing the researcher's conclusions about the research findings as they related to the literature review, identifying implications of the study, suggesting recommendations and providing a conclusion. The chapter was organized by sections and connected back to previous sections of the dissertation. The sections were purpose of the study, findings, discussion of results, limitations and recommendations for future research .

Finally, while the findings for reading maturity were not considered to have statistical power due to the small sample size the research study did allow preservice teachers to engage in authentic literacy experiences with fourth graders. It gave them opportunities to put into practice what they have been learning in their methods courses having allowed them to see and compare children's authentic responses to their higher order comprehension questions.

These experiences gave them insight into how children think. By participating in the research study and by the impromptu sharing of some preservice teachers with others, preservice teachers gained further insights into what awaits them in the real world when 
they go from being preservice teachers to inservice teachers. Their experiences also potentially gave them insight as to their level of preparedness in their process of striving to become teachers. Giving preservice teachers the opportunity to participate in authentic literacy experiences is a worthwhile pursuit as we endeavor to help prepare preservice teachers as they strive to become inservice teachers. 


\section{REFERENCES}

Abbitt, J. T. (2011). Measuring technological pedagogical content knowledge in preservice teacher education: A review of current methods and instruments. Journal of Research on Technology in Education, 43, 281-300.

Albion, P., \& Ertmer, P. (2002). Beyond the foundations: The role of vision and belief in teachers' preparation for integration of technology. TechTrends, 46(5), 34-38.

Applegate, A., \& Applegate, M. (2004). The peter effect: Reading habits and attitudes of preservice teachers. The Reading Teacher, 57(6), 554-563.

Applegate, A., Applegate, M., Mercantini, M., McGeehan, C., Cobb, J., Deboy, J., Modla, V., Lewinski, K. (2014). The peter effect revisited: Reading habits and attitudes of college students. Literacy Research and Instruction, 53(3), 188-204.

Berrill, D., \& Gall, M. (1999). On the carpet: Emergent writer/readers' letter sharing in a penpal program. Language Arts, 76, 470-78.

Bormuth, J. R. (1973 - 1974). Reading literacy: Its definition and assessment. Reading Research Quarterly, 9, 7-66. Retrieved from http://www.jstor.org/stable/747227

Bryan, L. A., \& Abell, S. K. (1999). Development of professional knowledge in learning to teach science. Journal of Research in Science Teaching, 36, 121-139.

Bull, G., Thompson, A., Searson, M., Garafalo, J., Park, J., Young, C., \& Lee, J. (2008). Connecting informal learning and formal learning: Experiences in the age of participatory media. Contemporary Issues in Technology and Teacher Education, 8, 100-107.

Campbell, T., \& Parr, M. (2013). Mapping today's literacy landscapes navigational tools and practices for the journey. Journal of Adolescent \& Adult Literacy, 57(2), 131140.

Carroll, P. S., \& Bowman, C. A. (2000). Leaping fire: Texts and technology. Contemporary Issues in Technology and Teacher Education, [Online serial], 1, 229-235.

Charron, N. N. (2007). "I learned that there's a state called victoria and he has six bluetongued lizards!" Reading Teacher, 60, 762-769.

Cunningham, J. W., Many, J. E., Carver, R. P., Gunderson, L., \& Mosenthal, P. B. (Jan. Feb. - Mar., 2000). Rrq snippet: How will literacy be defined in the new 
millenium? International Reading Association, 35, 64-71. Retrieved from http://www.jstor.org/stable/748287

Curtis, L. (2013). Literacy on the move: A journal for the journey. The Reading Teacher, 66(5), 372-376.

Daniels, E. (2007). Literacy cafe: Making writing authentic. Voices From the Middle, 14(3), 12-19.

Day, D. (2009). "A taste of college": Children and preservice teachers discuss books together. Journal of Research in Childhood Education, 23, 421-436.

Dede, C. (2010, 06 02). Transforming schooling via the 2010 national educational technology plan. Retrieved from http://www.tcrecord.org ID number: 15998

Demski, J. (2008). Networking e-palling around. T.H.E. Journal, Retrieved from www.corp.epals.com/download/E-Palling-Around-T.H.E._Journal.pdf

Dewey, J., Boydston, J. A., \& Gouinlock, J. (1984). John Dewey: The later works, 19251953. (Vol. 2, p. 57). Carbondale, IL: Southern Illinois University Press.

Dickinson, G., \& Summers, E. J. (2010). (Re)Anchored, video-centered engagement: The transferability of preservice training to practice. Contemporary Issues in Technology and Teacher Education, 10, 106-118.

Duke, N., Purcell-Gates, V., Hall, L., \& Tower, C. (2006) Authentic literacy activities for developing comprehension and writing. The Reading Teacher, 60, 344-355.

Englert, C. S. \& Palincsar, A. S. (1991). Reconsidering instructional research in literacy from a sociocultural perspective. Learning Disabilities Research and Practice, 20, 225-229.

Gambrell, L. B., Hughes, E. M., Calvert, L., Malloy, J. A., \& Igo, B. (2011). Authentic reading, writing, and discussion: An exploratory study of a pen pal project. The Elementary School Journal, 112, 234-258. Retrieved from http://www.jstor.org/stable/10.1086/661523.

Groenke, S. L. (2008). Missed opportunities in cyberspace: Preparing preservice teachers to facilitate critical talk about literature through computer-mediated communication. Journal of Adolescent \& Adult Literacy, 52, 224-233.

Hall, L., \& Hudson, R. (2006). Cross-curricular connections: video production in a k-8 teacher preparation program. Contemporary Issues in Technology and Teacher Education, 6, 328-341. 
Hinchman, K. A., \& Lalik, R. (2000). Power-knowledge formation in literacy teacher education: Exploring the perspective of two teacher educators. Journal of Educational Research, 93, 182-191.

Holt, D. M., McAllister, P., \& Ingram, E. C. (2002). 'Technology 2000'. Computers in the Schools, 18, 191-204. doi: Retrieved online on July 21, 2010 from [EBSCOHost EJS Content Distribution - Superseded by 916427733 url: http://dx.doi.org/10.1300/J025v18n04_04

Huang, J. (2013). Bridging authentic literacy experiences and literacy skills through the language experience approach. Journal of Adult Education, 42(1), 8-15.

Hughes, J., \& Robertson, L., (2010). Transforming practice: Using digital video to engage students. Contemporary Issues in Technology and Teacher Education, 10, 20-37.

Jewett, P. (2011). Multiple literacies gone wild. The Reading Teacher, 64(5), 341-344.

Johnson, D. (2010). Learning to teach: The influence of a university-school partnership project on preservice elementary teachers' efficacy for literacy instruction. Reading Horizons, 50, 23-48.

Lambert, J., \& Gong, Y. (2010). 21st century paradigms for preservice teacher technology preparation. Computers in the Schools, 27, 54-70.

LeVine, J. (2002). Writing letters to support literacy. The Reading Teacher, 56(3), 232234.

Mayer, R. E. (1996). Learning strategies for making sense out of expository text: The SOI model for guiding three cognitive processes in knowledge construction. Educational Psychology Review, 8, 357-371.

Medicus, D., \& Wood, S. (2000). The power of technology to inspire students and teachers in English language arts classrooms. Contemporary Issues in Technology and Teacher Education [Online serial], 1, 236-243.

McNeil, T., Newman, I., \& Kelly, F. J. (1996). Testing research hypotheses using the general linear model. Carbondale, IL: Southern Illinois University Press.

Mohan, L., Lundeberg, M. A., \& Reffitt, K. (2008). Studying teachers and schools: Michael pressley's legacy and directions for future research. Educational Psychologist, 43, 107-118

Moore, R. A., \& Seeger, V. (2009). Dear sincerely: Exploring literate identity with young children and preservice teachers through letter writing. Literacy Research and Instruction, 48, 185-205. 
Morgan, D. (2010). Preservice teachers as writers. Literacy Research and Instruction, 49(4), 352-365.

Morgan, D., \& Pytash, K. (2014). Preparing preservice teachers to become teachers of writing: A 20-year review of the research literature. English Education, 47(1), 636.

Nathanson, S., Pruslow, J., \& Levitt, R. (2008). The reading habits and literacy attitudes of inservice and prospective teachers: Results of a questionnaire survey. Journal of Teacher Education, 59(4), 313-321.

Newman, I., Newman, C., Brown, R., \& McNeely, S. (2006). Conceptual statistics for beginners. Carbondale, IL: Southern Illinois University Press.

Nixon-Ponder, S., \& Marshall, M. (1996). Exploring the use of authentic literature with adult learners. Journal of Adolescent \& Adult Literacy, 40(3), 216-217.

Parsons, S., \& Ward, A. (2011). The case for authentic tasks in content literacy. The Reading Teacher, 64(6), 462-465.

Pasternak, D.L. (2007). Is technology used as practice? A survey of preservice English teachers' perceptions and classroom practices. Contemporary Issues in Technology and Teacher Education, 7, 140-157.

Pierson, M. (2004). Extended time and progressive vision for the development of technology-using teachers. Contemporary issues in Technology and Teacher Education, 4, $81-88$.

Pohl, M. (2001). Learning to think, thinking to learn: Models and strategies to develop a classroom culture of thinking. Cheltenham, Vic.: Hawker Brownlow.

Purcell-Gates, V., Degener, S., Jacobson, E., \& Soler, M. (2002). Impact of authentic adult literacy instruction on adult literacy practices. Reading Research Quarterly, 37(1), 70-92.

Raphael, T. \& Englert, C. S. (1989). Integrating writing and reading instruction. In. P.Winograd, K. Wixson, \& M. Lipson, (Eds.). Improving basal reading instruction (pp.231-255). New York, NY: Teachers College Press.

Schmidt, D. A., Baran, E., Thompson, A. D., Koehler, M. J., Mishra, P., \& Shin, T. (2009). Survey of preservice teachers' knowledge of teaching and technology. Retrieved from http://www.sjrbiz.info/Webliography Lists/TPACK Survey.pdf

Schmidt, D. A., Baran, E., Thompson, A. D., Mishra, P., Koehler, M. J., \& Shin, T. S. (2009/2010). Technological pedagogical content knowledge (tpack): The development and validation of an assessment instrument for preservice teachers. Journal of research on technology in education, 42, 123-149. Retrieved from 
http://learnonline.canberra.edu.au/pluginfile.php/491591/mod_page/content/1/TP ACK_UC/pdf/tpack4_preservice2.pdf

Schmoker, M. (2007). Radically redefining literacy instruction: An immense opportunity. Phi Delta Kappan, 88(7), 488-493.

Shoffner, M. (2009). "Because I know how to use it": Integrating technology into preservice English teacher reflective practice. Contemporary Issues in Technology and Teacher Education, 9, 371-391.

Solvie, P., \& Kloek, M. (2007). Using technology tools to engage students with multiple learning styles in a constructivist learning environment. Contemporary Issues in Technology and Teacher Education, 7, 7-27.

Tarlinton, D. (2003, July 14). Revised Bloom's Taxonomy. Retrieved July 20, 2011, from http://www.kurwongbss.qld. edu.au/thinking/Bloom/blooms.htm

Teale, W. H., \& Gambrell, L. B. (2007). Raising urban students' literacy learning achievement by engaging in authentic, challenging work. Reading Teacher, 60, 728-739.

Teale, W.H., Leu, D.J., Jr., Labbo, L.D., Kinzer, C. (2002, April). The CTELL project: New ways technology can help educate tomorrow's reading teachers [Exploring Literacy on the Internet department]. The Reading Teacher, 55. Available: http://www.readingonline.org/electronic/elec index.asp?HREF=/electronic/RT/4$\underline{02 \text { Column/index.html }}$

Teale, W. H., Zolt, N., Yokota, J., Glasswell, K., \& Gambrell, L. (2007). Getting children In2Books: Engagement in authentic reading, writing, and thinking. Phi Delta Kappan, 88, 498-502.

Tebo-Messina, M., \& Blough, D. (1989). Penpals and keypals--networks for student writers. Paper presented at the Annual spring conference of the national council of teachers of English, Charleston, SC. Retrieved from http://www.eric.ed.gov/PDFS/ED321257.pdf

Theiss, D., Philbrick, A., \& Jarman, G. (2008-2009). Using the reading maturity survey in teacher education program evaluation. SRATE Journal, 18, 59-63.

Thomas, M. (2001). The reading maturity survey. Retrieved from http://faculty.ucmo.edu/readingmaturity/

Thomas, M. (2013). Looking ahead with hope: Reviving the reading maturity construct as social science for adolescent and adult readers. Reading Horizons, 52(2), 142162. 
U.S. Dept. of Education. (1996). Getting America's students ready for the 21st century: Meeting the technology literacy challenge. Washington, DC.

U.S. Department of Education. (2010). Draft 2010 national educational technology plan. Retrieved from website: http://www.ed.gov/technology/net p-2010

U.S. Department of Education. (2010). The educator accomplished practices (9648413). Retrieved from website: https://www.flrules.org/gateway/ruleno.asp?id=6A-5.065

Valdez, G., M., McNabb, M., Foertsch, M., Anderson, M., Hawkes, M., \& Raack. (2000). Computer-based technology and learning: Evolving uses and expectations. Retrieved from http://www.eric.ed.gov/ERICWebPortal/detail?accno=ED456816

Van Sluys, K., Laman, T. T., Legan, N., \& Lewison, M. (2005). Critical literacy and preservice teachers: Changing definitions of what it might mean to read. Journal of Reading Education, 31, 13-22.

Vygotsky, L. S. (1978). Mind in society: The development of higher psychological process. Cambridge, MA: Harvard University Press.

Wang, J., \& Odell, S. J. (n.d.). Mentored learning to teach according to standards-based reform: A critical review. Review of Educational Research, 72, 481-546. Retrieved from http://www.jstor.org/stable/3515994

Willes, E. \& Raines, P. (2001). Technology and the changing face of teacher preparation. Contemporary Issues in Technology and Teacher Education [Online serial], 1, 412-420.

Wold, L. S., Grisham, D. L., Farnan, N., Lenski, S. D., \& Members of the Teacher Education Research Study Group (TERSG), (2008). Examining the research on critical issues in literacy teacher education. Journal of Reading Education, 33, 1120.

Wolf, S., Mieras, E., \& Carey, A. (1996). What's after "what's that?": Preservice teachers learning to ask literary questions. Journal of Literacy Research, 28(4), 459-497.

Woodcock, C. (2009). Fight the dragons: Using online discussion to promote critical literacy in teacher education. Contemporary Issues in Technology and Teacher Education, 9, 95-116. 
APPENDICES 
Appendix A

Book Bloggers - Friendly Letter

Preservice Teachers 


\section{Book Buddies - Friendly Letter}

City, State ZIP

Date

Dear

My name is and I'm in school to become a teacher. So far my school year has been great! On weekdays I work on What do you do in school? Tell me about your favorite subject.

I spend most of my weekends at . My favorite thing to do during my free time is . What are some of the things you do for fun? I have been playing lots of . Do you play any sports/games?

I have a pet whose name is . Do you have a pet? If yes please tell me all about it. If you don't have a pet but could pick anything as your pet what would it be? Why?

I hope that school has been going well for you too. We are going to have a great time as Book Bloggers. I can't wait to start reading our first book.

Your friend, Signature 


\section{Appendix B}

Survey of Preservice Teachers' Knowledge of Teaching and Technology

Version 1.1: (updated September 1, 2009) 


\section{Survey of Preservice Teachers' Knowledge of Teaching and Technology}

Denise A. Schmidt, Evrim Baran, and Ann D. Thompson

Center for Technology in Learning and Teaching

Iowa State University

Matthew J. Koehler, Punya Mishra, and Tae Shin

Michigan State University

Usage Terms: Researchers are free to use the TPACK survey, provided they contact Dr.

Denise Schmidt (dschmidt@iastate.edu) with a description of their intended usage

(research questions, population, etc.), and the site locations for their research. The goal is to maintain a database of how the survey is being used, and keep track of any translations of the survey that exist.

Version 1.1: (updated September 1, 2009). This survey was revised to reflect research results obtained from its administration during the 2008-2009 and 2009-2010 academic years. This document provides the latest version of the survey and reports the reliability scores for each TPACK domain. (This document will be updated as the survey is further developed).

The following papers and presentations highlight the development process of this survey:

Schmidt, D. A., Baran, E., Thompson A. D., Koehler, M. J., Mishra, P. \& Shin, T. (2009$10)$.

Technological Pedagogical Content Knowledge (TPACK): The Development and Validation of an Assessment Instrument for Preservice Teachers. Journal of Research on Technology in Education, 42(2), 123-149. 
Schmidt, D. A., Baran, E., Thompson A. D., Koehler, M. J., Mishra, P. \& Shin, T. (2009). The Continuing Development, Validation and Implementation of a TPACK Assessment Instrument for Preservice Teachers. Paper submitted to the 2010 Annual Meeting of the American Educational Research Association. April 30-May 4, Denver, CO.

Schmidt, D., Baran, E., Thompson, A., Koehler, M.J., Shin, T, \& Mishra, P. (2009, April). Technological Pedagogical Content Knowledge (TPACK): The Development and Validation of an Assessment Instrument for Preservice Teachers. Paper presented at the 2009 Annual Meeting of the American Educational Research Association. April 13-17, San Diego, CA.

Schmidt, D., Baran, E., Thompson, A., Koehler, M.J., Mishra, P., \& Shin, T. (2009, March). Examining preservice teachers’ development of technological pedagogical content knowledge in an introductory instructional technology course. Paper presented at the 2009 International Conference of the Society for the Information and Technology \& Teacher Education. March 2-6, Charleston, SC.

Shin, T., Koehler, M.J., Mishra, P. Schmidt, D., Baran, E., \& Thompson, A., (2009, March). Changing technological pedagogical content knowledge (TPACK) through course experiences. Paper presented at the 2009 International Conference of the Society for the Information and Technology \& Teacher Education. March 2-6, Charleston, SC.

How do I use the survey? The questions you want are most likely questions 1-46 starting under the header "TK (Technology Knowledge)". In the papers cited above, these 
categories were removed so that participants were not oriented to the constructs when answering the survey questions. The items were presented in order from 1 through 46 , however. The other items are more particular to individual study and teacher education context to better understand results found on questions 1-46. You are free to use them, or modify them. However, they are not the core items used to measure the components of TPACK.

Note: For the purposes of this study the researcher only used questions 1-46.

How do I score the survey? Each item response is scored with a value of 1 assigned to strongly disagree, all the way to 5 for strongly agree. For each construct the participant's responses are averaged. For example, the 6 questions under TK (Technology Knowledge) are averaged to produce one TK (Technology Knowledge) Score.

Reliability of the Scores (from Schmidt et al, 2009).

\section{TPACK Domain Internal Consistency (alpha)}

Technology Knowledge (TK) .86

Content Knowledge (CK)

Social Studies .82

Mathematics .83

Science .78

Literacy .83

Pedagogy Knowledge (PK) .87

Pedagogical Content Knowledge (PCK) .87

Technological Pedagogical Knowledge (TPK) 93

Technological Content Knowledge (TCK) .86

Technological Pedagogical Content Knowledge (TPACK) 89 
Thank you for taking time to complete this questionnaire. Please answer each question to the best of your knowledge. Your thoughtfulness and candid responses will be greatly appreciated. Your individual name or identification number will not at any time be associated with your responses. Your responses will be kept completely confidential and will not influence your course grade.

\section{DEMOGRAPHIC INFORMATION}

1. Your FIU e-mail address

2. Gender

a. Female

b. Male

3. Age range

a. $18-22$

b. $23-26$

c. $27-32$

d. $32+$

4. Major

a. Elementary Education (ELED)

b. Other

5. Year in College

a. Freshman

b. Sophomore

c. Junior

d. Senior

6. Are you completing an educational computing minor?

a. Yes

b. No

7. Are you currently enrolled or have you completed a practicum experience in a PreK-6 classroom?

a. Yes

b. No

8. What semester and year (e.g. Spring 2008) do you plan to take the following? If you are currently enrolled in or have already taken one of these literacy blocks please list semester and year completed

\begin{tabular}{|l|l|}
\hline RED 3313 Language and Literacy Development & \\
\hline RED 4150 Content and Methods of Teaching Beginning & \\
Literacy & \\
\hline RED 4311 Content and Methods of Teaching Intermediate & \\
Literacy & \\
\hline
\end{tabular}


RED 4110 Content and Methods of Teaching Literacy in Schools

Student teaching

Technology is a broad concept that can mean a lot of different things. For the purpose of this questionnaire, technology is referring to digital technology/technologies. That is, the digital tools we use such as computers, laptops, iPods, handhelds, interactive whiteboards, software programs, etc. Please answer all of the questions and if you are uncertain of or neutral about your response you may always select "Neither Agree or Disagree".

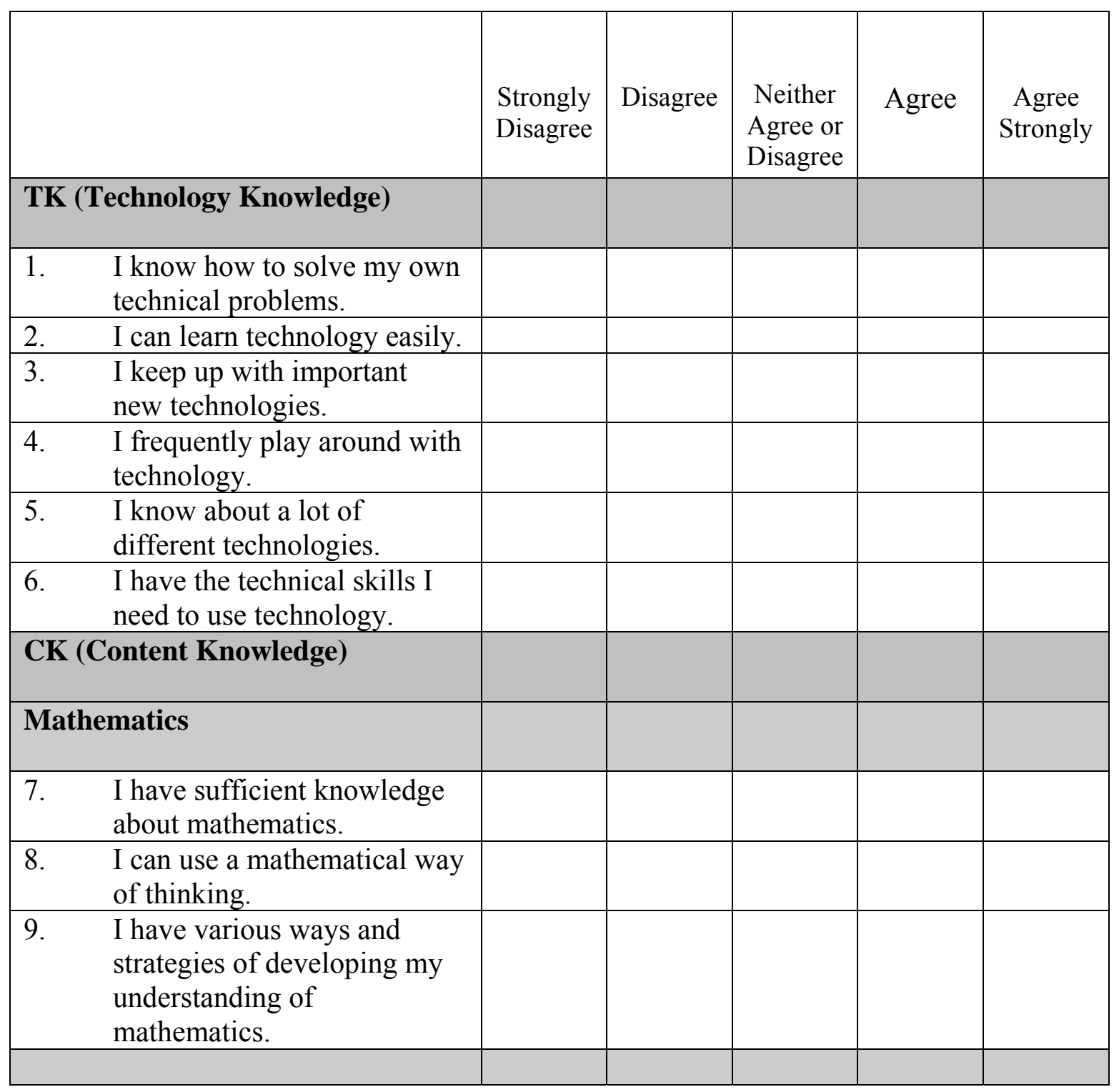




\begin{tabular}{|c|c|c|c|c|c|c|}
\hline & & $\begin{array}{l}\text { Strongly } \\
\text { Disagree }\end{array}$ & Disagree & $\begin{array}{l}\text { Neither } \\
\text { Agree or } \\
\text { Disagree }\end{array}$ & Agree & $\begin{array}{l}\text { Agree } \\
\text { Strongly }\end{array}$ \\
\hline \multicolumn{7}{|c|}{ Social Studies } \\
\hline & $\begin{array}{l}\text { I have sufficient knowledge } \\
\text { about social studies. }\end{array}$ & & & & & \\
\hline 11. & $\begin{array}{l}\text { I can use a historical way of } \\
\text { thinking. }\end{array}$ & & & & & \\
\hline 12. & $\begin{array}{l}\text { I have various ways and } \\
\text { strategies of developing my } \\
\text { understanding of social } \\
\text { studies. }\end{array}$ & & & & & \\
\hline \multicolumn{7}{|c|}{ Science } \\
\hline & $\begin{array}{l}\text { I have sufficient knowledge } \\
\text { about science. }\end{array}$ & & & & & \\
\hline & $\begin{array}{l}\text { I can use a scientific way of } \\
\text { thinking. }\end{array}$ & & & & & \\
\hline & $\begin{array}{l}\text { I have various ways and } \\
\text { strategies of developing my } \\
\text { understanding of science. }\end{array}$ & & & & & \\
\hline \multicolumn{7}{|c|}{ Literacy } \\
\hline & $\begin{array}{l}\text { I have sufficient knowledge } \\
\text { about literacy. }\end{array}$ & & & & & \\
\hline & $\begin{array}{l}\text { I can use a literary way of } \\
\text { thinking. }\end{array}$ & & & & & \\
\hline 18. & $\begin{array}{l}\text { I have various ways and } \\
\text { strategies of developing my } \\
\text { understanding of literacy. }\end{array}$ & & & & & \\
\hline 19. & $\begin{array}{l}\text { I know how to assess student } \\
\text { performance in a classroom. }\end{array}$ & & & & & \\
\hline & $\begin{array}{l}\text { I can adapt my teaching } \\
\text { based-upon what students } \\
\text { currently understand or do } \\
\text { not understand. }\end{array}$ & & & & & \\
\hline & $\begin{array}{l}\text { I can adapt my teaching style } \\
\text { to different learners. }\end{array}$ & & & & & \\
\hline & $\begin{array}{l}\text { I can assess student learning } \\
\text { in multiple ways. }\end{array}$ & & & & & \\
\hline & $\begin{array}{l}\text { I can use a wide range of } \\
\text { teaching approaches in a }\end{array}$ & & & & & \\
\hline
\end{tabular}




\begin{tabular}{|c|c|c|c|c|c|c|}
\hline & & $\begin{array}{l}\text { Strongly } \\
\text { Disagree }\end{array}$ & Disagree & $\begin{array}{l}\text { Neither } \\
\text { Agree or } \\
\text { Disagree }\end{array}$ & Agree & $\begin{array}{l}\text { Agree } \\
\text { Strongly }\end{array}$ \\
\hline & classroom setting. & & & & & \\
\hline & $\begin{array}{l}\text { I am familiar with common } \\
\text { student understandings and } \\
\text { misconceptions. }\end{array}$ & & & & & \\
\hline 25. & $\begin{array}{l}\text { I know how to organize and } \\
\text { maintain classroom } \\
\text { management. }\end{array}$ & & & & & \\
\hline \multicolumn{2}{|c|}{$\begin{array}{l}\text { PCK (Pedagogical Content } \\
\text { Knowledge) }\end{array}$} & & & & & \\
\hline & $\begin{array}{l}\text { I can select effective teaching } \\
\text { approaches to guide student } \\
\text { thinking and learning in } \\
\text { mathematics. }\end{array}$ & & & & & \\
\hline & $\begin{array}{l}\text { I can select effective teaching } \\
\text { approaches to guide student } \\
\text { thinking and learning in } \\
\text { literacy. }\end{array}$ & & & & & \\
\hline & $\begin{array}{l}\text { I can select effective teaching } \\
\text { approaches to guide student } \\
\text { thinking and learning in } \\
\text { science. }\end{array}$ & & & & & \\
\hline & $\begin{array}{l}\text { I can select effective teaching } \\
\text { approaches to guide student } \\
\text { thinking and learning in } \\
\text { social studies. }\end{array}$ & & & & & \\
\hline \multicolumn{2}{|c|}{$\begin{array}{l}\text { TCK (Technological Content } \\
\text { Knowledge) }\end{array}$} & & & & & \\
\hline & $\begin{array}{l}\text { I know about technologies } \\
\text { that I can use for } \\
\text { understanding and doing } \\
\text { mathematics. }\end{array}$ & & & & & \\
\hline & $\begin{array}{l}\text { I know about technologies } \\
\text { that I can use for } \\
\text { understanding and } \\
\text { doing literacy. }\end{array}$ & & & & & \\
\hline & $\begin{array}{l}\text { I know about technologies } \\
\text { that I can use for } \\
\text { understanding and }\end{array}$ & & & & & \\
\hline
\end{tabular}




\begin{tabular}{|c|c|c|c|c|c|c|}
\hline & & $\begin{array}{l}\text { Strongly } \\
\text { Disagree }\end{array}$ & Disagree & $\begin{array}{l}\text { Neither } \\
\text { Agree or } \\
\text { Disagree }\end{array}$ & Agree & $\begin{array}{l}\text { Agree } \\
\text { Strongly }\end{array}$ \\
\hline & doing science. & & & & & \\
\hline & $\begin{array}{l}\text { I know about technologies } \\
\text { that I can use for } \\
\text { understanding and doing } \\
\text { social studies. }\end{array}$ & & & & & \\
\hline \multicolumn{7}{|c|}{$\begin{array}{l}\text { TPK (Technological Pedagogical } \\
\text { Knowledge) }\end{array}$} \\
\hline 34. & $\begin{array}{l}\text { I can choose technologies } \\
\text { that enhance the teaching } \\
\text { approaches for a lesson. }\end{array}$ & & & & & \\
\hline 35. & $\begin{array}{l}\text { I can choose technologies } \\
\text { that enhance students' } \\
\text { learning for a lesson. }\end{array}$ & & & & & \\
\hline 36. & $\begin{array}{l}\text { My teacher education } \\
\text { program has caused me to } \\
\text { think more deeply about how } \\
\text { technology could influence } \\
\text { the teaching approaches I use } \\
\text { in my classroom. }\end{array}$ & & & & & \\
\hline 37. & $\begin{array}{l}\text { I am thinking critically about } \\
\text { how to use technology in my } \\
\text { classroom. }\end{array}$ & & & & & \\
\hline 38. & $\begin{array}{l}\text { I can adapt the use of the } \\
\text { technologies that I am } \\
\text { learning about to different } \\
\text { teaching activities. }\end{array}$ & & & & & \\
\hline & $\begin{array}{l}\text { I can select technologies to } \\
\text { use in my classroom that } \\
\text { enhance what I teach, how I } \\
\text { teach and what students } \\
\text { learn. }\end{array}$ & & & & & \\
\hline 40. & $\begin{array}{l}\text { I can use strategies that } \\
\text { combine } \\
\text { content, technologies and } \\
\text { teaching approaches that I } \\
\text { learned about in my } \\
\text { coursework in my classroom. }\end{array}$ & & & & & \\
\hline & $\begin{array}{l}\text { I can provide leadership in } \\
\text { helping others to coordinate }\end{array}$ & & & & & \\
\hline
\end{tabular}




\begin{tabular}{|c|c|c|c|c|c|c|}
\hline & & $\begin{array}{l}\text { Strongly } \\
\text { Disagree }\end{array}$ & Disagree & $\begin{array}{l}\text { Neither } \\
\text { Agree or } \\
\text { Disagree }\end{array}$ & Agree & $\begin{array}{l}\text { Agree } \\
\text { Strongly }\end{array}$ \\
\hline & $\begin{array}{l}\text { the use of content, } \\
\text { technologies and } \\
\text { teaching approaches at my } \\
\text { school and/or district. }\end{array}$ & & & & & \\
\hline 42. & $\begin{array}{l}\text { I can choose technologies } \\
\text { that enhance the content for a } \\
\text { lesson. }\end{array}$ & & & & & \\
\hline \multicolumn{7}{|c|}{$\begin{array}{l}\text { TPACK (Technology Pedagogy } \\
\text { and Content Knowledge) }\end{array}$} \\
\hline 43. & $\begin{array}{l}\text { I can teach lessons that } \\
\text { appropriately combine } \\
\text { mathematics, technologies } \\
\text { and teaching approaches. }\end{array}$ & & & & & \\
\hline 44. & $\begin{array}{l}\text { I can teach lessons that } \\
\text { appropriately combine } \\
\text { literacy, technologies and } \\
\text { teaching approaches. }\end{array}$ & & & & & \\
\hline & $\begin{array}{l}\text { I can teach lessons that } \\
\text { appropriately combine } \\
\text { science, technologies and } \\
\text { teaching approaches. }\end{array}$ & & & & & \\
\hline & $\begin{array}{l}\text { I can teach lessons that } \\
\text { appropriately combine social } \\
\text { studies, technologies and } \\
\text { teaching approaches. }\end{array}$ & & & & & \\
\hline
\end{tabular}




\section{Survey of Preservice Teachers' Knowledge of Teaching and Technology}

(with categories deleted)

Thank you for taking time to complete this questionnaire. Please answer each question to the best of your knowledge. Your thoughtfulness and candid responses will be greatly appreciated. Your individual name or identification number will not at any time be associated with your responses. Your responses will be kept completely confidential and will not influence your course grade.

\section{DEMOGRAPHIC INFORMATION}

1. Your FIU e-mail address

2. Gender

a. Female

b. Male

3. Age range

a. $18-22$

b. $23-26$

c. $27-32$

d. $32+$

4. Major

a. Elementary Education (ELED)

b. Other

5. Year in College

a. Freshman

b. Sophomore

c. Junior

d. Senior

6. Are you completing an educational computing minor?

a. Yes

b. No

7. Are you currently enrolled or have you completed a practicum experience in a PreK-6 classroom?

a. Yes

b. No

8. What semester and year (e.g. Spring 2008) do you plan to take the following? If you are currently enrolled in or have already taken one of these literacy blocks please list semester and year completed

\begin{tabular}{|l|l|}
\hline RED 3313 Language and Literacy Development & \\
\hline RED 4150 Content and Methods of Teaching Beginning & \\
Literacy & RED 4311 Content and Methods of Teaching Intermediate \\
Literacy \\
\hline RED 4110 Content and Methods of Teaching Literacy in & \\
Schools & \\
\hline Student teaching & \\
\hline
\end{tabular}


Technology is a broad concept that can mean a lot of different things. For the purpose of this questionnaire, technology is referring to digital technology/technologies. That is, the digital tools we use such as computers, laptops, iPods, handhelds, interactive whiteboards, software programs, etc. Please answer all of the questions and if you are uncertain of or neutral about your response you may always select "Neither Agree or Disagree".

\begin{tabular}{|c|c|c|c|c|c|c|}
\hline & & $\begin{array}{l}\text { Strongly } \\
\text { Disagree }\end{array}$ & Disagree & $\begin{array}{l}\text { Neither } \\
\text { Agree or } \\
\text { Disagree }\end{array}$ & Agree & $\begin{array}{l}\text { Agree } \\
\text { Strongly }\end{array}$ \\
\hline 1. & $\begin{array}{l}\text { I know how to solve my own } \\
\text { technical problems. }\end{array}$ & & & & & \\
\hline 2. & I can learn technology easily. & & & & & \\
\hline 3. & $\begin{array}{l}\text { I keep up with important new } \\
\text { technologies. }\end{array}$ & & & & & \\
\hline 4. & $\begin{array}{l}\text { I frequently play around with } \\
\text { technology. }\end{array}$ & & & & & \\
\hline 5. & $\begin{array}{l}\text { I know about a lot of different } \\
\text { technologies. }\end{array}$ & & & & & \\
\hline 6. & $\begin{array}{l}\text { I have the technical skills I } \\
\text { need to use technology. }\end{array}$ & & & & & \\
\hline 7. & $\begin{array}{l}\text { I have sufficient knowledge } \\
\text { about mathematics. }\end{array}$ & & & & & \\
\hline 8. & $\begin{array}{l}\text { I can use a mathematical way } \\
\text { of thinking. }\end{array}$ & & & & & \\
\hline 9. & $\begin{array}{l}\text { I have various ways and } \\
\text { strategies of developing my } \\
\text { understanding of } \\
\text { mathematics. }\end{array}$ & & & & & \\
\hline 10. & $\begin{array}{l}\text { I have sufficient knowledge } \\
\text { about social studies. }\end{array}$ & & & & & \\
\hline 11. & $\begin{array}{l}\text { I can use a historical way of } \\
\text { thinking. }\end{array}$ & & & & & \\
\hline 12. & $\begin{array}{l}\text { I have various ways and } \\
\text { strategies of developing my } \\
\text { understanding of social } \\
\text { studies. }\end{array}$ & & & & & \\
\hline 13. & $\begin{array}{l}\text { I have sufficient knowledge } \\
\text { about science. }\end{array}$ & & & & & \\
\hline 14. & I can use a scientific way of & & & & & \\
\hline
\end{tabular}




\begin{tabular}{|c|c|c|c|c|c|c|}
\hline & & $\begin{array}{l}\text { Strongly } \\
\text { Disagree }\end{array}$ & Disagree & $\begin{array}{l}\text { Neither } \\
\text { Agree or } \\
\text { Disagree }\end{array}$ & Agree & $\begin{array}{l}\text { Agree } \\
\text { Strongly }\end{array}$ \\
\hline & thinking. & & & & & \\
\hline 15. & $\begin{array}{l}\text { I have various ways and } \\
\text { strategies of developing my } \\
\text { understanding of science. }\end{array}$ & & & & & \\
\hline 16. & $\begin{array}{l}\text { I have sufficient knowledge } \\
\text { about literacy. }\end{array}$ & & & & & \\
\hline 17. & $\begin{array}{l}\text { I can use a literary way of } \\
\text { thinking. }\end{array}$ & & & & & \\
\hline 18. & $\begin{array}{l}\text { I have various ways and } \\
\text { strategies of developing my } \\
\text { understanding of literacy. }\end{array}$ & & & & & \\
\hline 19. & $\begin{array}{l}\text { I know how to assess student } \\
\text { performance in a classroom. }\end{array}$ & & & & & \\
\hline 20. & $\begin{array}{l}\text { I can adapt my teaching } \\
\text { based- upon what students } \\
\text { currently understand or do not } \\
\text { understand. }\end{array}$ & & & & & \\
\hline 21. & $\begin{array}{l}\text { I can adapt my teaching style } \\
\text { to different learners. }\end{array}$ & & & & & \\
\hline 22. & $\begin{array}{l}\text { I can assess student learning } \\
\text { in multiple ways. }\end{array}$ & & & & & \\
\hline 23. & $\begin{array}{l}\text { I can use a wide range of } \\
\text { teaching approaches in a } \\
\text { classroom setting. }\end{array}$ & & & & & \\
\hline 24. & $\begin{array}{l}\text { I am familiar with common } \\
\text { student understandings and } \\
\text { misconceptions. }\end{array}$ & & & & & \\
\hline 25. & $\begin{array}{l}\text { I know how to organize and } \\
\text { maintain classroom } \\
\text { management. }\end{array}$ & & & & & \\
\hline 26. & $\begin{array}{l}\text { I can select effective teaching } \\
\text { approaches to guide student } \\
\text { thinking and learning in } \\
\text { mathematics. }\end{array}$ & & & & & \\
\hline 27. & $\begin{array}{l}\text { I can select effective teaching } \\
\text { approaches to guide student } \\
\text { thinking and learning in } \\
\text { literacy. }\end{array}$ & & & & & \\
\hline 28. & $\begin{array}{l}\text { I can select effective teaching } \\
\text { approaches to guide student }\end{array}$ & & & & & \\
\hline
\end{tabular}




\begin{tabular}{|c|c|c|c|c|c|c|}
\hline & & $\begin{array}{l}\text { Strongly } \\
\text { Disagree }\end{array}$ & Disagree & $\begin{array}{l}\text { Neither } \\
\text { Agree or } \\
\text { Disagree }\end{array}$ & Agree & $\begin{array}{l}\text { Agree } \\
\text { Strongly }\end{array}$ \\
\hline & $\begin{array}{l}\text { thinking and learning in } \\
\text { science. }\end{array}$ & & & & & \\
\hline 29. & $\begin{array}{l}\text { I can select effective teaching } \\
\text { approaches to guide student } \\
\text { thinking and learning in social } \\
\text { studies. }\end{array}$ & & & & & \\
\hline 30. & $\begin{array}{l}\text { I know about technologies } \\
\text { that I can use for } \\
\text { understanding and doing } \\
\text { mathematics. }\end{array}$ & & & & & \\
\hline 31. & $\begin{array}{l}\text { I know about technologies } \\
\text { that I can use for } \\
\text { understanding and doing } \\
\text { literacy. }\end{array}$ & & & & & \\
\hline 32. & $\begin{array}{l}\text { I know about technologies } \\
\text { that I can use for } \\
\text { understanding and doing } \\
\text { science. }\end{array}$ & & & & & \\
\hline 33. & $\begin{array}{l}\text { I know about technologies } \\
\text { that I can use for } \\
\text { understanding and doing } \\
\text { social studies. }\end{array}$ & & & & & \\
\hline 34. & $\begin{array}{l}\text { I can choose technologies that } \\
\text { enhance the teaching } \\
\text { approaches for a lesson. }\end{array}$ & & & & & \\
\hline 35. & $\begin{array}{l}\text { I can choose technologies that } \\
\text { enhance students' learning for } \\
\text { a lesson. }\end{array}$ & & & & & \\
\hline 36. & $\begin{array}{l}\text { My teacher education } \\
\text { program has caused me to } \\
\text { think more deeply about how } \\
\text { technology could influence } \\
\text { the teaching approaches I use } \\
\text { in my classroom. }\end{array}$ & & & & & \\
\hline 37. & $\begin{array}{l}\text { I am thinking critically about } \\
\text { how to use technology in my } \\
\text { classroom. }\end{array}$ & & & & & \\
\hline 38 & $\begin{array}{l}\text { I can adapt the use of the } \\
\text { technologies that I am } \\
\text { learning about to different }\end{array}$ & & & & & \\
\hline
\end{tabular}




\begin{tabular}{|c|c|c|c|c|c|c|}
\hline & & $\begin{array}{l}\text { Strongly } \\
\text { Disagree }\end{array}$ & Disagree & $\begin{array}{l}\text { Neither } \\
\text { Agree or } \\
\text { Disagree }\end{array}$ & Agree & $\begin{array}{l}\text { Agree } \\
\text { Strongly }\end{array}$ \\
\hline & teaching activities. & & & & & \\
\hline 39. & $\begin{array}{l}\text { I can select technologies to } \\
\text { use in my classroom that } \\
\text { enhance what I teach, how I } \\
\text { teach and what students learn. }\end{array}$ & & & & & \\
\hline 40. & $\begin{array}{l}\text { I can use strategies that } \\
\text { combine content, technologies } \\
\text { and teaching approaches that I } \\
\text { learned about in my } \\
\text { coursework in my classroom. }\end{array}$ & & & & & \\
\hline 41. & $\begin{array}{l}\text { I can provide leadership in } \\
\text { helping others to coordinate } \\
\text { the use of content, } \\
\text { technologies and teaching } \\
\text { approaches at my school } \\
\text { and/or district. }\end{array}$ & & & & & \\
\hline 42. & $\begin{array}{l}\text { I can choose technologies that } \\
\text { enhance the content for a } \\
\text { lesson. }\end{array}$ & & & & & \\
\hline 43. & $\begin{array}{l}\text { I can teach lessons that } \\
\text { appropriately combine } \\
\text { mathematics, technologies } \\
\text { and teaching approaches. }\end{array}$ & & & & & \\
\hline 44. & $\begin{array}{l}\text { I can teach lessons that } \\
\text { appropriately combine } \\
\text { literacy, technologies and } \\
\text { teaching approaches. }\end{array}$ & & & & & \\
\hline 45. & $\begin{array}{l}\text { I can teach lessons that } \\
\text { appropriately combine } \\
\text { science, technologies and } \\
\text { teaching approaches. }\end{array}$ & & & & & \\
\hline 46. & $\begin{array}{l}\text { I can teach lessons that } \\
\text { appropriately combine social } \\
\text { studies, technologies and } \\
\text { teaching approaches. }\end{array}$ & & & & & \\
\hline
\end{tabular}


Appendix C

The Reading Maturity Survey 


\section{The Reading Maturity Survey}

\section{Overview}

“The Reading Maturity Survey (previously The Reading Survey; Thomas, 2001) is a simple self-report survey instrument designed to assess reading maturity. In their seminal work with reading maturity, Gray and Rogers (1956) initially attempted to examine a set of subcategories that they felt best constituted the reading maturity construct. In more recent efforts to define and measure the reading maturity construct, the author of The Reading Maturity Survey interpreted, applied, and in some cases extended or adjusted these into six subcategories influenced also some by the work of Casale (1982), Manzo and Casale (1981, 1983a, 1983b), and Manzo, Manzo, Barnhill, and Thomas (2000)). These categories are labeled as follows: reading attitudes and interests; reading purposes; reading ability; reaction to and use of ideas to apprehend (higher-order literacy); kind of materials read; and personal adjustment to reading/transformational reading. The Reading Maturity Survey has six subcategories, one for each of these six elements of reading maturity" (Thomas, 2001).

The survey contains 60 questions, 10 from each of the six subcategories. Each question is answered on a 5-point Likert scale ( $5=$ "a lot like me", $3=$ "somewhat like me", and 1 = "not like me"). The score for The Reading Maturity Survey, which can be treated as interval scale data, is the mean of the 60 item scores for an individual. The subcategory scores for each of the six areas of reading maturity can also be generated. Split-half reliability was calculated in an earlier study (Thomas, 2001), when it was given to 82 college students, using the six subcategory scores of each instrument. The correlation between halves was .85 
and when the Spearman-Brown formula was used to estimate the reliability coefficient for the whole instrument, it was .92. It has no time limits but is estimated to take approximately 20 minutes to complete.

The high internal reliability of The Reading Maturity Survey (.92) provides some validity and a sense of coherence to the six subcategories of reading maturity that the author of the instrument developed under the influence of Gray and Rogers' (1956) foundational study; it is clear that these fairly diverse six categories do appropriately and meaningfully fit together. This may reasonably be said to contribute a new degree of clarification and coherence to current understanding of the reading maturity construct. As such The Reading Maturity Survey provides a reliable and simple way for at least starting to measure reading maturity, allowing the topic to now be more easily revisited and examined by educational practitioners (Thomas, 2001).

"For practical use of this survey with individuals and groups, it is recommended that each respondent's responses/scores be examined individually in order to begin identifying self-reported strengths and weaknesses relative to the various aspects of the reading maturity construct. To compare means between individuals may not be helpful, but to identify relative high and low scores on particular items for an individual may allow for the sensible formation of subsequent "action plans" to continue building on strengths and addressing weaknesses with the long-term goal of promoting growth toward reading maturity. (Thomas, 2001). 


\section{Permissions}

The Reading Maturity Survey was written by Matt Thomas, Ph.D., University of Central Missouri. For more information on this instrument, including permission to copy and use (for free), please contact him at: mthomas@ucmo.edu or 660-543-8729. Thanks.

\section{References}

Casale, U. P. (1982). Small group approach to the further validation and refinement of a battery for assessing "progress toward reading maturity" (Doctoral dissertation, University of Missouri-Kansas City, 1982). Dissertation Abstracts International, 43, 770A.

Gray, W.S., \& Rogers, B. (1956). Maturity in reading: Its nature and appraisal. Chicago, IL: University of Chicago Press.

Manzo, A. V. \& Casale, U. P. (1981). A multivariate analysis of principle and trace elements in mature reading comprehension. In G.H. McNinch (Ed.), Comprehension: Process and product. Online Yearbook of the American Reading Forum, Vol. I (pp. 29-36). Accessed June 26, 2006 from: http://www.americanreadingforum.org/81_yearbook/pdf/09_Manzo.pdf

Manzo, A. V., \& Casale, U. P. (1983a). Description and factor analysis of a broad spectrum battery for assessing "progress toward reading maturity." In G.H. McNinch (Ed.), Reading research to reading practice. Online Yearbook of the American Reading Forum, Vol. III (pp. 100-105). Accessed June 26, 2006 from: http://www.americanreadingforum.org/83_yearbook/pdf/43_Manzo.pdf 
Manzo, A. V., \& Casale, U. P. (1983b). A preliminary description and factor analysis of a broad spectrum battery for assessing "progress toward reading maturity." Reading Psychology, 4(2), 181-191.

Manzo, A. V., Manzo, U., Barnhill, A., \& Thomas, M. (2000). Proficient reader subtypes: Implications for literacy theory, assessment, and practice. Reading Psychology, 21(3), 217-232.

Thomas, M. M. (2001). Proficient reader characteristics: Relationships among text-dependent and higher-order literacy variables with reference to stage theories of intellectual development. Dissertation Abstracts International, (UMI No. 3010626)

(C)2007 Matt Thomas

The Reading Maturity Survey http://faculty.ucmo.edu/readingmaturity/ 
(C) M.M. Thomas, 2001

The Reading Maturity Survey

The Reading Maturity Survey

Name/ID:

Age:

Date:

Directions: Please rate/characterize yourself as a reader on each item. Use the five point scale where one (1) is the lowest and five (5) is the highest.

\section{Section 1}

1. I enjoy reading. not like me 12

somewhat like me

4

a lot like me

5

2. I have a high interest in reading.

\begin{tabular}{llcll} 
not like me & \multicolumn{3}{c}{ somewhat like me } & a lot like me \\
1 & 2 & 3 & 4 & 5
\end{tabular}

3. I feel that reading can be exciting.

\begin{tabular}{llcll} 
not like me & \multicolumn{3}{c}{ somewhat like me } & a lot like me \\
1 & 2 & 3 & 4 & 5
\end{tabular}

4. Reading can be stimulating.

\begin{tabular}{llcll} 
not like me & \multicolumn{3}{c}{ somewhat like me } & a lot like me \\
1 & 2 & 3 & 4 & 5
\end{tabular}

5. Reading is an important part of my life.

\begin{tabular}{llcll} 
not like me & \multicolumn{3}{c}{ somewhat like me } & a lot like me \\
1 & 2 & 3 & 4 & 5
\end{tabular}

6. I read frequently.

\begin{tabular}{llcll} 
not like me & \multicolumn{3}{c}{ somewhat like me } & a lot like me \\
1 & 2 & 3 & 4 & 5
\end{tabular}

7. I have a wide variety (or breadth) of reading interests.

not like me somewhat like me

1
4

a lot like me 5

8. I like to read about many different things. not like me 1 somewhat like me

23

a lot like me 5 
9. I read extensively on certain topics (or with depth).

\begin{tabular}{llcll} 
not like me & \multicolumn{3}{c}{ somewhat like me } & a lot like me \\
1 & 2 & 3 & 4 & 5
\end{tabular}

10. I enjoy reading to learn a lot about something that interests me.

\begin{tabular}{llcll} 
not like me & \multicolumn{3}{c}{ somewhat like me } & a lot like me \\
1 & 2 & 3 & 4 & 5
\end{tabular}

\section{Section 2}

1. I feel that I read for valuable reasons.

\begin{tabular}{llcll} 
not like me & \multicolumn{3}{c}{ somewhat like me } & a lot like me \\
1 & 2 & 3 & 4 & 5
\end{tabular}

2. One of the reasons that I read is for pleasure.

\begin{tabular}{llcll} 
not like me & \multicolumn{3}{c}{ somewhat like me } & a lot like me \\
1 & 2 & 3 & 4 & 5
\end{tabular}

3. One of the reasons I read is to learn more about things that interest me. not like me 1 somewhat like me 45

4. One of the reasons I read is to gain new knowledge. not like me somewhat like me

$\begin{array}{lllll}1 & 2 & 3 & 4 & 5\end{array}$
a lot like me 5

5. One of the reasons I read is to improve my understanding of life. not like me 1 somewhat like me $2 \quad 3$ 4 a lot like me 5

6. One of the reasons I read is to understand others better. not like me 1 somewhat like me 3 4 a lot like me 5

7. One of the reasons I read is to understand myself better. not like me 1 somewhat like me 2 3 4 a lot like me 5 
8. I try to actively engage myself with what I am reading.

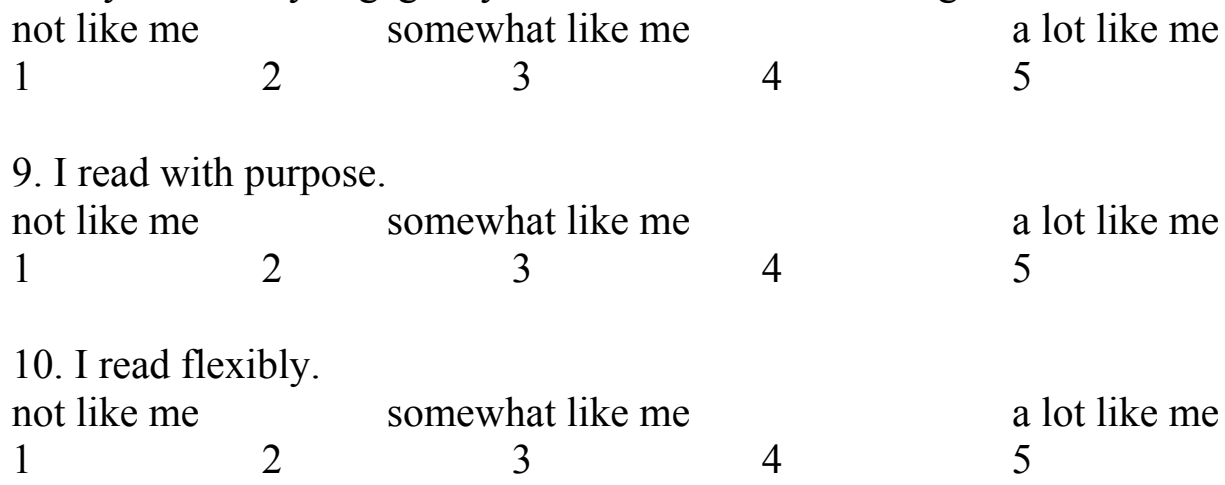

\section{Section 3}

1. I can read proficiently.

\begin{tabular}{llcll} 
not like me & \multicolumn{3}{c}{ somewhat like me } & a lot like me \\
1 & 2 & 3 & 4 & 5
\end{tabular}

2. I understand most of what I read.

\begin{tabular}{llcll} 
not like me & \multicolumn{3}{c}{ somewhat like me } & a lot like me \\
1 & 2 & 3 & 4 & 5
\end{tabular}

3. When I read, I feel like I get a good grasp of the literal meaning being presented.

\begin{tabular}{llcll} 
not like me & \multicolumn{3}{c}{ somewhat like me } & a lot like me \\
1 & 2 & 3 & 4 & 5
\end{tabular}

4. I am comfortable with my reading ability.

\begin{tabular}{llcll} 
not like me & \multicolumn{3}{c}{ somewhat like me } & a lot like me \\
1 & 2 & 3 & 4 & 5
\end{tabular}

5. I feel like I have the ability to see implied meanings in what I read.

\begin{tabular}{llcll} 
not like me & \multicolumn{3}{c}{ somewhat like me } & a lot like me \\
1 & 2 & 3 & 4 & 5
\end{tabular}

6. I don't mind reading out loud.

\begin{tabular}{llcll} 
not like me & \multicolumn{3}{c}{ somewhat like me } & a lot like me \\
1 & 2 & 3 & 4 & 5
\end{tabular}


7. I feel like I can "read the lines" efficiently.

$\begin{array}{llcll}\text { not like me } & & \text { somewhat like me } & \text { a lot like me } \\ 1 & 2 & 3 & 4 & 5\end{array}$

8. I feel like I can "read between the lines" efficiently.

$\begin{array}{llcll}\text { not like me } & & \text { somewhat like me } & \text { a lot like me } \\ 1 & 2 & 3 & 4 & 5\end{array}$

9. I can read fluently.

$\begin{array}{llcll}\text { not like me } & & \text { somewhat like me } & \text { a lot like me } \\ 1 & 2 & 3 & 4 & 5\end{array}$

10. My school grades and test scores would indicate that I have good reading comprehension abilities.

$\begin{array}{llcll}\text { not like me } & & \text { somewhat like me } & \text { a lot like me } \\ 1 & 2 & 3 & 4 & 5\end{array}$

\section{Section 4}

1. While I read something, I often think of other things that I already know about the topic.

not like me somewhat like me a lot like me

$\begin{array}{lllll}1 & 2 & 3 & 4 & 5\end{array}$

2. Reading prompts me with new ideas and insights.

not like me somewhat like me a lot like me

$\begin{array}{lllll}1 & 2 & 3 & 4 & 5\end{array}$

3. I often make generalizations and personal conclusions about what I have read. not like me somewhat like me a lot like me $\begin{array}{llllll}1 & 2 & 3 & 4 & 5\end{array}$

4. Reading helps me make decisions about things.

$\begin{array}{llccc}\text { not like me } & & \text { somewhat like me } & \text { a lot like me } \\ 1 & 2 & 3 & 4 & 5\end{array}$


5. When I read, I combine ideas I already have with ideas that I read to form new personal understandings.

$\begin{array}{llccc}\text { not like me } & \text { somewhat like me } & \text { a lot like me } \\ 1 & 2 & 3 & 4 & 5\end{array}$

6. I read with an inquiring attitude.

$\begin{array}{llccc}\text { not like me } & \text { somewhat like me } & \text { a lot like me } \\ 1 & 2 & 3 & 4 & 5\end{array}$

7. I ask myself questions while I am reading.

$\begin{array}{llccc}\text { not like me } & & \text { somewhat like me } & \text { a lot like me } \\ 1 & 2 & 3 & 4 & 5\end{array}$

8. When I evaluate the main idea of what I am reading, I look for supporting points.

not like me somewhat like me a lot like me

$\begin{array}{lllll}1 & 2 & 3 & 4 & 5\end{array}$

9. When I am reading, I often recognize ideas that may have personal or societal value. not like me somewhat like me a lot like me

$\begin{array}{lllll}1 & 2 & 3 & 4 & 5\end{array}$

10. I construct new ideas from what I read.

$\begin{array}{ccccc}\text { not like me } & \text { somewhat like me } & \text { a lot like me } \\ 1 & 2 & 3 & 4 & 5\end{array}$

\section{Section 5}

1. I read intellectually challenging material.

$\begin{array}{llccc}\text { not like me } & & \text { somewhat like me } & \text { a lot like me } \\ 1 & 2 & 3 & 4 & 5\end{array}$

2. I enjoy reading material that goes beyond "easy-reading." not like me somewhat like me a lot like me $\begin{array}{lllll}1 & 2 & 3 & 4 & 5\end{array}$ 
3. I like to read things that make me think.

\begin{tabular}{llccc} 
not like me & \multicolumn{3}{c}{ somewhat like me } & a lot like me \\
1 & 2 & 3 & 4 & 5
\end{tabular}

4. There are rich ideas in the materials that I read.

not like me somewhat like me a lot like me

$\begin{array}{llllll}1 & 2 & 3 & 4 & 5\end{array}$

5. I enjoy reading about things that stimulate my mind.

\begin{tabular}{llccc} 
not like me & \multicolumn{3}{c}{ somewhat like me } & a lot like me \\
1 & 2 & 3 & 4 & 5
\end{tabular}

6. I often read materials that are at relatively difficult reading levels.

not like me somewhat like me a lot like me

$\begin{array}{lllll}1 & 2 & 3 & 4 & 5\end{array}$

7. I enjoy reading materials that help me better understand other people.

not like me somewhat like me a lot like me

$\begin{array}{llllll}1 & 2 & 3 & 4 & 5\end{array}$

8. I often read things that broaden my understanding of the world.

not like me somewhat like me a lot like me

$\begin{array}{lllll}1 & 2 & 3 & 4 & 5\end{array}$

9. I am intellectually enriched by most of what I read.

not like me somewhat like me a lot like me

$\begin{array}{lllll}1 & 2 & 3 & 4 & 5\end{array}$

10. I enjoy reading materials that teach me things I did not know before.

not like me somewhat like me a lot like me

$\begin{array}{lllll}1 & 2 & 3 & 4 & 5\end{array}$

\section{Section 6}

1. Reading often helps me change my perspective about things.

not like me

1 somewhat like me

3 a lot like me

5 
2. Reading often makes me want to make personal changes in my life.

$\begin{array}{llccc}\text { not like me } & & \text { somewhat like me } & \text { a lot like me } \\ 1 & 2 & 3 & 4 & 5\end{array}$

3. When I learn something valuable from credible reading sources, I usually apply it to the actions my life.

not like me

somewhat like me

a lot like me

1

2

3

4

5

4. Reading can transform my actions.

not like me

somewhat like me

1

2

3

a lot like me

45

5. Reading can transform my thinking. not like me somewhat like me 1 2 3

a lot like me

45

6. Reading can transform my values.

not like me

somewhat like me

1

2

3

a lot like me

45

7. I can recall instances in which I have been personally transformed from things I have read.

not like me somewhat like me

1

23

3

a lot like me

5

8. Reading makes me carefully consider changes I should make in my life.

not like me somewhat like me 1 23

4 5

9. Reading often causes me to be personally reflective. not like me 1 somewhat like me 23 a lot like me

45

10. Some of my character is shaped by what I read. not like me 1 somewhat like me a lot like me 2 3

45


Name/ID:

\section{Reading Maturity Survey \\ Tabulation Sheet}

\section{Tabulations}

Section 1: Interest in Reading

Sum Score:

Section 2: Purposes for Reading

Sum Score:

Section 3: The Recognition and Reconstruction of Meaning

Sum Score:

Section 4: Reaction To and Use of Ideas to Apprehend (Higher-Order Literacy)

Sum Score:

Section 5: Kinds of Materials Read

Sum Score:

Section 6: Personal Adjustment to Reading/Transformational Reading

Sum Score:

Total of Sum Scores: $/ 60=$

\section{TOTAL READING MATURITY SCORE}

The Reading Maturity Survey was written by Matt Thomas, Ph.D., University of Central Missouri. For more information on this instrument, including permission to copy and use (for free), please contact him at: mthomas@ucmo.edu or 660-543-8729. Thanks. 
Appendix D

List of Books Read

by

Book Buddies and Hispanic Fourth Graders 


\section{List of Books Read}

by

Book Buddies and Hispanic Fourth Graders

Narrative Texts:

- Flat Stanley's Worldwide Adventures \#9: The US Capital Commotion by Jeff Brown

- The Chocolate Touch by Patrick Skene Catling

- Charlotte's Web by E. B. White

Informational Text:

- Life in the Rainforest (Smart Words Reader) by Christine A. Caputo 
Appendix E

Preservice Teachers as Book Buddies Timeline 


\begin{tabular}{|c|l|}
\hline \multicolumn{2}{|c|}{ Preservice Teachers as Book Buddies Timeline } \\
Vivian Veiga - Dissertation Project \\
Spring 2014
\end{tabular}


Appendix F

From Revised Bloom's Taxonomy

by

D. Tarlinton (2003) 


\section{From Revised Bloom's Taxonomy \\ by \\ D. Tarlinton (2003)}

\section{Questions for Analyzing}

- Which events could not have happened?

- If. ... happened, what might the ending have been?

- How is...similar to...?

- What do you see as other possible outcomes?

- Why did...changes occur?

- Can you explain what must have happened when...?

- What are some or the problems of...?

- Can you distinguish between...?

- What were some of the motives behind..?

- What was the turning point?

- What was the problem with...?

\section{Questions for Evaluating}

- Is there a better solution to...?

- Judge the value of...

- What do you think about...?

- Can you defend your position about...?

- Do you think...is a good or bad thing?

- How would you have handled...?

- What changes to.. would you recommend?

- Do you believe...?

- How would you feel if. ..?

- How effective are. ..?

- What are the consequences..?

- What influence will....have on our lives?

- What are the pros and cons of....?

- Why is ....of value?

- What are the alternatives?

- Who will gain \& who will lose?

(Pohl, Learning to Think, Thinking to Learn, p. 13 


\section{From Revised Bloom's Taxonomy \\ by \\ D. Tarlinton (2003) \\ Questions for Creating}

- Can you design a...to...?

- Can you see a possible solution to...?

- If you had access to all resources, how would you deal with...?

- Why don't you devise your own way to...?

- What would happen if...?

- How many ways can you...?

- Can you create new and unusual uses for...?

- Can you develop a proposal which would...?

(Pohl, Learning to Think, Thinking to Learn, p. 14)

\section{Source:}

Tarlinton, D. (2003, July 14). Revised Bloom's Taxonomy. Retrieved July 20, 2011, from http://www.kurwongbss.qld. edu.au/thinking/Bloom/blooms.htm 
Appendix G

Sample Letters from Preservice Teachers

and

Hispanic Fourth Graders’ Responses 
Dear

I just finished reading the book Flat Stanley's Worldwide Adventures and I loved it! This story was about the US Capital. I really enjoyed this book because it was the first Flat Stanley book I ever read. My favorite part of the story was when Stanley met with the President and helped him realize that he was a hero and that he deserved the medal of honor. The most interesting part for me was when I read the different places Stanley had been like Mount Rushmore or the Egyptian pyramids. What was your favorite part of the story? If Stanley would have ran away for a longer time, what do you think the consequences could have been? What do you think are the pros and cons of being Flat Stanley? What do you think makes a hero?

I hope to hear from you soon!

Your Friend, 


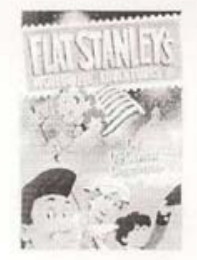

Dear

What is your favorite sub ject? These are the answers to your questions

Mr when stanley climbs up the Washington $2 \mathrm{His}$ parents waild have loft

3 The pros it that youcan so under doors and the cons are that wind can blow you away 4 That he soes onlote of ad ventures

Your friend,

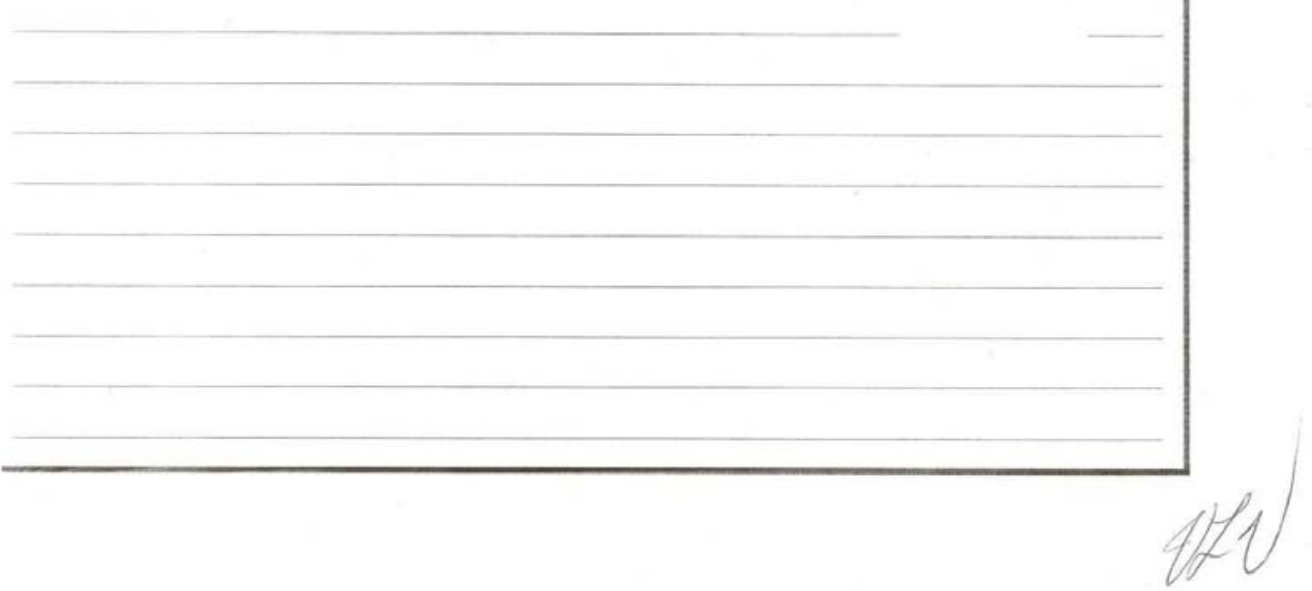




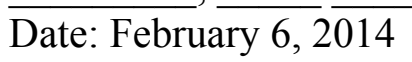

Dear

How are you? Sorry that it took a while for me to write you back. I read Flat Stanley and it was a really good book. Even though I considered it pleasure-reading, it contained a lot of cool and important facts such as the Lincoln Memorial, the US Capitol. Did you notice any other fun facts that are in the book? I was fascinated that Stanley was flat and that the President of the United States was a woman! How cool is that? Like Stanley, I would've been disappointed that my parents made me be a flag in the parade. I loved this book and can't wait to read the next. A few questions I have for you are:

1. What do you think the turning point was for Stanley?

2. How would you have handled meeting the mayor of the state?

3. What would happen if you were chosen to get an award from the President of the United States? How would you feel?

Until next time, have a Great Week!

Sincerely, (;) 


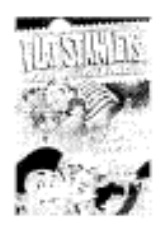

Dear How are you today? Well the

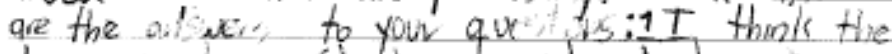
turning powt 1,5taing was when he became flat. 2 I ve woult hove haid te d it Telling him or "ie';

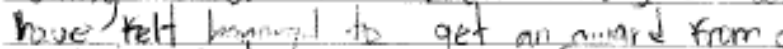
prestant What is your frivite color. Your friend is...

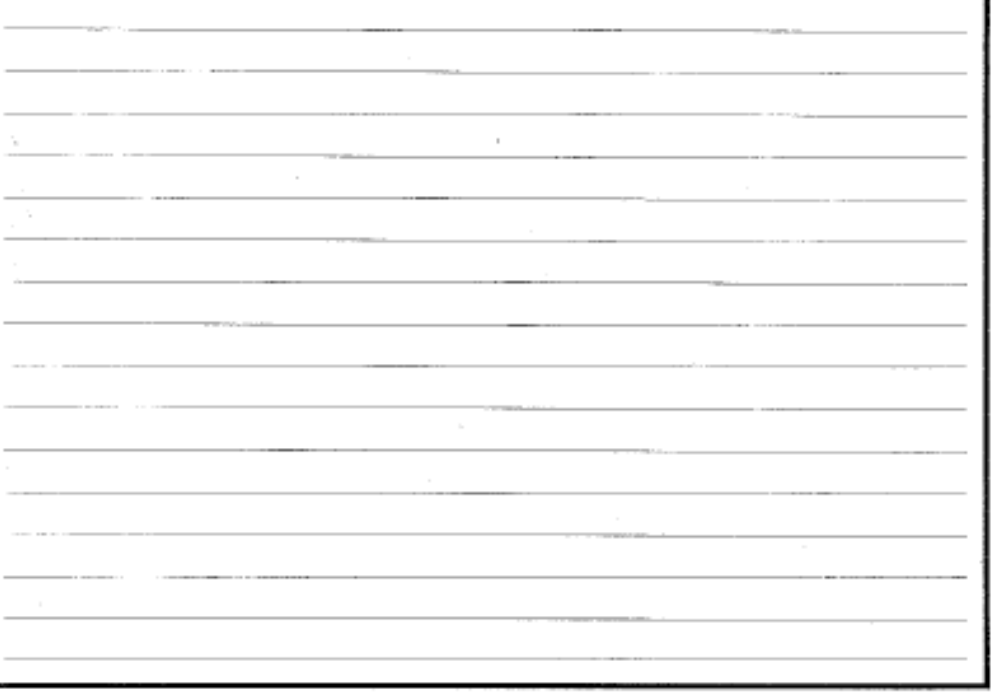


VITA

\section{VIVIAN LUCIA VEIGA}

Born, Habana, Cuba

1993-1995

B.S. in Education

Florida Memorial College

Miami, FL

1996 - Present

Teacher

Kensington Park Elementary

Miami, FL

$1998-1999$

1998- 2000

2000 - Present

2001

2002

2007 - Present

Council for Exceptional Children (CEC) Mainstreaming

Teacher of the Year - Kensington Park Elementary

Miami, Florida

Council for Exceptional Children (CEC)

Mainstreaming Teacher of the Year, First Runner Up,

District - Miami-Dade County

M.S. in Education

Advanced Professional Studies in Teaching and Learning

University of Miami,

Miami, Florida

Mentor and Candidate Support Provider for National Board University of Miami's Project SUCCEED Network

Mentoring and Induction for New Teachers (MINT)

New Educator Support Team (NEST)

Miami, Florida

Middle Childhood Generalist

National Board for Professional Teaching Standards

Miami, Florida

Participant - National Air \& Space Administration - NASA

Educator Workshop (NEW)

Kennedy Space Center

Cocoa Beach, Florida

Instructional Strategies That Work (ISTW): Became ER\&D Trainer Educational Research \& Dissemination

Summer and Winter Institutes. Tampa and Orlando, Florida 
$2008-2012$

2010

2012

2013 - Present

$2007-2014$
Project RISE National Board Certified Teacher School site grant coordinator/ Prof. Development Trainer Miami-Dade County Public Schools

Middle Childhood Generalist Recertification National Board for Professional Teaching Standards Miami, Florida

AFT TEACH National Trainer / National Trainer Academy 2012 for Instructional Strategies That Work for All Disciplines (ISTWAD), and Reading Comprehension Instruction (RCI) Trainer, Maritime Institute Baltimore, Maryland

Board Member of the UTD Teaching Excellence Foundation, Inc. Board - United Teachers of Dade Miami, Florida

Doctoral Candidate

Florida International University

Miami, Florida

\section{PRESENTATIONS}

Veiga, V. (2001, May) Co-Presenter - University of Miami's Science for All Project: Measurement Unit Presentation for selected San Francisco Bay Area Teachers and selected University of California at Berkeley faculty and staff. Loma Linda Elementary, San Francisco, CA.

Veiga, V. Co-Presenter (2002, April) - University of Miami, Science for All Project American Educational Research Association (AERA) and National Association for Research in Science Teaching (NARST) National / International Conferences, New Orleans, LA.

Veiga, V. (2002, October) Co-Presenter - Working Inclusively to Reach Excellence with Diverse Abilities (WIRED), Miami-Dade County Public Schools - Instructional Technology Conference Version 10 Miami Beach Convention Center, Miami, FL.

Veiga, V. (2002, May) Presenter - Setting Up for Success (In Co-Teaching / Inclusion) Detroit Public Schools System, Detroit, MI. 